\title{
Phosphorylation of DARPP-32 and Protein Phosphatase Inhibitor-1 in Rat Choroid Plexus: Regulation by Factors Other Than Dopamine
}

\author{
Gretchen L. Snyder, ${ }^{1}$ Jean-Antoine Girault, ${ }^{1, a}$ Jonathan Y. C. Chen, ${ }^{2}$ Andrew J. Czernik, ${ }^{1}$ John W. Kebabian, ${ }^{2}$ \\ James A. Nathanson, ${ }^{3}$ and Paul Greengard ${ }^{1}$ \\ 'Laboratory of Molecular and Cellular Neuroscience, The Rockefeller University, New York, New York 10021, \\ 2Neuroscience Research, Abbott Laboratories, Abbott Park, Illinois 60064, and 'Department of Neurology and Program in \\ Neuroscience, Harvard Medical School, Massachusetts General Hospital, Boston, Massachusetts 02114
}

\begin{abstract}
The molecular mechanisms underlying regulation of fluid production by secretory epithelia such as the choroid plexus are poorly understood. Two cAMP-regulated inhibitors of protein phosphatase-1, inhibitor-1 $\left(I_{1}\right)$ and a dopamine- and CAMP-regulated phosphoprotein, $M_{r}=32,000$ (DARPP-32), are enriched in the choroid plexus. We show here that these two phosphoproteins are colocalized in choroid plexus epithelial cells. We have developed a novel method for studying the phosphorylation state of DARPP-32 and $\mathrm{I}_{1}$ in intact cells, using a phosphorylation state-specitic monoclonal antibody. Several drugs and hormones that are known to alter fluid secretion and that increase CAMP levels (forskolin, isoproterenol, vasoactive intestinal peptide) or cGMP levels (atrial natriuretic peptide) or that may use additional second messenger pathways (5-HT), increase the phosphorylation of $\mathrm{I}_{1}$ and DARPP-32 in rat choroid plexus. In contrast, dopamine does not alter CAMP and CGMP levels, or $I_{1}$ and DARPP-32 phosphorylation. Our results indicate that DARPP32, known to be regulated by dopamine in a number of tissues, can be phosphorylated in response to non-dopaminergic factors, including hormones acting through noncAMP-dependent pathways. Our results also raise the possibility that inhibition of phosphatase-1, as a result of $I$, and DARPP-32 phosphorylation, might be part of a final common pathway in the action of several factors that are known or thought to alter cerebrospinal fluid production.
\end{abstract}

Cerebrospinal fluid (CSF) is formed in and secreted from epithelial cells of choroid plexus (for review, see Cserr, 1971). Although the physiological events underlying CSF production are beginning to be understood (see Johanson, 1989, for recent review), the mechanisms that regulate this essential process re-

\footnotetext{
Received Oct. 28, 1991; revised Mar. 12, 1992; accepted Mar. 16, 1992.

We thank Drs. Angus Nairn, Hugh Hemmings, Jr., and Atsuko Horiuchi for providing cAMP-dependent protein kinase catalytic subunit and antibodies against DARPP-32 and inhibitor-1, and Drs. Angus Nairn and Robert MacKenzie for helpful discussions of the experiments. The excellent technical assistance of Edwin Gomez and Michael Steffey in measurements of cAMP levels and Edward Hunnicutt and Mary Rose Deak in various aspects of the study is gratefully acknowledged. We also thank Kathleen Sweadner for the K2 antiserum to Na,K-ATPase. G.L.S. was a postdoctoral fellow at Abbott Laboratories during a portion of this investigation. This research was supported by Grant MH40899 to P.G. and U.S. PIIS Grant EY05077 to J.A.N.

Correspondence should be addressed to Gretchen L. Snyder, The Rockefeller University, Department of Molecular and Cellular Neuroscience, 1230 York Avenue, Box 296, New York, NY 10021.

a Present address: INSERM U114, College de France, Paris Cedex 05.

Copyright (C) 1992 Society for Neuroscience $0270-6474 / 92 / 123071-13 \$ 05.00 / 0$
}

main unclear. There is some evidence that CSF production is under neural and hormonal control and that some of the neurotransmitters and hormones involved act through the regulation of cAMP. For example, drugs that directly increase cAMP levels by activating adenylyl cyclase (i.e., cholera toxin or forskolin) have been reported to alter the rate of (SF production in choroid plexus (Epstein et al., 1977; Feldman et al., 1979) and the ratc of aqucous humor production from the physiologically analogous ciliary process (Gregory et al., 1981; Caprioli et al., 1984). Several neurotransmitters and hormones, including norepinephrine and vasoactive intestinal peptide (VIP), also stimulate cAMP formation in choroid plexus and have been hypothesized to influence CSF production by this mechanism (Nathanson, 1979, 1980; Crook et al., 1984; Lindvall et al., 1985; Crook and Prusiner, 1986). However, at present, the mechanisms by which cAMP might alter CSF formation are unknown.

Neurotransmitters and hormones acting through cAMP are known to modulate cellular processes by the reversible phosphorylation of proteins (Nestler and Greengard, 1984). One class of regulated phosphoproteins that has been postulated to play a role in the mediation of cAMP-associated hormone action is the protein phosphatase inhibitors, DARPP-32 (i.e., dopamineand cAMP-regulated phosphoprotein, $M_{r}=32,000$ ) (Walaas et al., 1983a,b; Hemmings et al., 1984b; Walaas and Greengard, $1984)$ and inhibitor-1 $\left(I_{1}\right)$ (Ingebritsen and Cohen, 1983; Ingebritsen et al., 1983). Both proteins are phosphorylated by cAMPdependent protein kinase on a single threonyl residue and, in phosphorylated form, are potent inhibitors of protein phosphatase- 1 in vitro (Hemmings et al., 1984a). DARPP-32 is abundant in brain neurons possessing the dopamine $\mathrm{D}_{1}$-receptor (e.g., medium-sized striatonigral neurons) (Ouimet et al., 1984; Hemmings and Greengard, 1986) and is phosphorylated in these cells in response to dopamine acting through cAMP-dependent protein kinase (Walaas et al., 1983a,b). DARPP-32 is also found in high concentration in the choroid plexus (Hemmings and Greengard, 1986; Steardo and Nathanson, 1987). However, prior reports suggest that dopamine is a poor activator of adenylyl cyclase in this tissue and there is no evidence for a distinct dopamine-sensitive adenylyl cyclase (Nathanson, 1980). Because DARPP-32 phosphorylation has previously been shown to be regulated only by dopamine, this finding raises the question of whether DARPP-32 is uniquely a dopamine-regulated protein and whether DARPP-32 and homologous phosphoproteins might be involved in the action of other hormones and neurotransmitters. 


\section{DARPP-32 \\ 20 LDPRQVEM IRRRRPTPAMLFR ${ }_{21}^{L}$ DPRQVEM I RRRRPTPATLV L CAMP-KINASE}

\section{INHIBITOR-1}

Figure 1. Amino acid sequences surrounding the cAMP-dependent phosphorylation sites of bovine DARPP-32 (upper sequence) and rabbit or rat $I_{1}$ (lower sequence). CAMP-dependent protein kinase phosphorylates a threonyl residue in a homologous region of both proteins, $\mathrm{Thr}_{34}$ in DARPP-32 (Hemmings et al., 1984c) and $\mathrm{Thr}_{35}$ in $\mathrm{I}_{1}$ (Cohen et al., 1977). The sequence of the synthetic peptide that was phosphorylated and used for immunization is indicated by a box. One letter amino acid codes are used: $A$, alanine; $D$, aspartate; $E$, glutamate; $F$, phenylalanine; $I$, isolcucinc; $L$, leucine; $M$, methionine; $P$, proline; $Q$, glutamine; $R$, arginine; $T$, threonine; $V$, valine. The sequences are from bovine caudate DARPP-32 (Williams et al., 1986) and rabbit or rat skeletal muscle $I_{1}$ (Aitken et al., 1982; Elbrecht et al., 1990).

The present study investigates the possibility that other neurotransmitters and hormones known to regulate adenylyl cyclase activity in choroid plexus might regulate the phosphorylation state of DARPP-32 and $I_{1}$ in intact tissue. In addition, we examine the possibility that other choroid plexus-enriched hormone receptors known to activate cAMP-independent pathways may also participate in this regulation. To study the state of phosphorylation of DARPP-32 and $I_{1}$, we have used a phosphorylation state-selective monoclonal antibody raised against a phosphopeptide encompassing the DARPP-32 cAMP-dependent phosphorylation site. Given the almost identical sequence of DARPP-32 and $I_{1}$ in that region, the antibody also recognizes the phosphorylated form of $I_{1}$.

\section{Materials and Methods}

Forskolin, atrial natriuretic factor (ANF; rat sequence), and Pansorbin [Staphylococcus aureus cells (SACs)] were obtained from Calbiochem (San Diego, CA). RPMI 1640 media, Nonidet P-40, vasoactive intestinal peptide (VIP; rat sequence), rabbit anti-mouse IgG, phenylmethylsulfonyl fluoride (PMSF), bovine serum albumin (BSA), isoproterenol $\mathrm{HCl}$, serotonin (5-hydroxytryptamine $\mathrm{HCl})$, 8-bromo-cyclic GMP (8bromo-guanosine $3^{\prime}: 5^{\prime}$ cyclic-monophosphate), and dopamine (3-hydroxytyramine $\mathrm{HCl}$ ) were purchased from Sigma Chemical Co. (St. Louis, MO). Acrylamide and nitrocellulose membrane were obtained from Bio-Rad Laboratories (Richmond, CA). ${ }^{125}$ I-labeled protein A and $\gamma^{32}$ P-ATP were from New England Nuclear (Cambridge, MA). SpragueDawley rats and pregnant CD-1 mice were supplied by Charles River Laboratories (Wilmington, MA). Catalytic subunit of cyclic AMP-dependent protein kinase purified to homogeneity as described by Kaczmarek et al. (1980) was kindly supplied by Dr. Angus Nairn and Atsuko Horiuchi. DARPP-32 was purified from bovine caudate nucleus by a modification of the previously described method (Hemmings et al., 1984b; Williams et al., 1986), including chromatography on DE-52 (Whatman), acid extraction, ammonium sulfate fractionation, and sequential chromatography on DEAE-Sephacel (LKB-Pharmacia), HAUltrogel (IBF), and Mono-Q (LKB-Pharmacia). Monoclonal antibodies against DARPP-32 (C24-4D7, -5A, and -6A) (Hemmings and Greengard, 1986) were a gift of Dr. Hugh Hemmings. Monoclonal antibodies C24-5A and $-6 \mathrm{~A}$ but not 4D7 display a slight (approximately 1:3000) cross-reactivity with $I_{1}$. The $K_{2}$ antibody, selective for the kidney (al) form of Na,K-ATPase, was kindly provided by Dr. Kathleen Sweadner

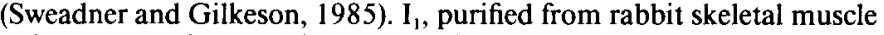
(Nimmo and Cohen, 1978; Hemmings et al., 1984d), and a highly specific rabbit antiserum (G 187) directed against $I_{1}$ were provided by Drs. Angus Nairn and Hugh Hemmings.

\section{Preparation of phosphopeptide antigens and phosphoproteins}

The synthetic peptide chosen for immunization was a 10-residue peptide encompassing the cyclic AMP-dependent phosphorylation site $\left(\mathrm{Thr}_{34}\right)$ of bovine DARPP-32 corresponding to residues 28-37 (Hemmings et al., 1984c; Williams et al., 1986). The sequence of the peptide was $\mathrm{NH}_{2}-$ Ile-Arg-Arg-Arg-Arg-Pro-Thr-Pro-Ala-Met-CONH ${ }_{2}$. This sequence is identical to that surrounding the cyclic AMP-dependent phosphorylation site in rat and rabbit $I_{1}$ with the exception of the methionine residue in DARPP-32, which is a threonine in $I_{1}$ (Aitken et al., 1982; Elbrecht et al., 1990; see Fig. 1). Note also that the Met $_{37}$ in bovine DARPP-32 is replaced by a leucine in the rat sequence (Ehrlich et al., 1990). The peptide was synthesized by Dr. J. Elliot at the Yale University Protein and Nucleic Acid Chemistry Facility, by the solid-phase method (Hodges and Merrifield, 1975) using a model 430A Applied Biosystems Peptide Synthesizer, and was purified by preparative reverse-phase HPLC using two Vydac $\mathrm{C}_{18}$ columns $(25 \times 250 \mathrm{~mm})$ in series. Purity was estimated to be $>95 \%$ by analytical HPLC and amino acid analysis, and was verified by mass spectrometry (data not shown).

The synthetic peptide was phosphorylated in vitro by the catalytic subunit of cyclic AMP-dependent protein kinase. A typical reaction mixture contained $2 \mathrm{~mm}$ peptide, $5 \mathrm{~mm} \gamma^{32} \mathrm{P}$-ATP (specific activity, 0.3 $\mathrm{Ci} / \mathrm{mol}), 10 \mu \mathrm{g} / \mathrm{ml}$ catalytic subunit, $50 \mathrm{~mm}$ HEPES, $\mathrm{pH} 7.4,10 \mathrm{~mm}$ magnesium acetate, and $1 \mathrm{mM}$ EGTA in a volume of $6 \mathrm{ml}$. Incubation was carried out for $18 \mathrm{hr}$ at $30^{\circ} \mathrm{C}$ and stopped by addition of $3 \mathrm{ml}$ of glacial acetic acid. Dowex AG $1-\mathrm{XB}(2 \mathrm{ml})$ was added, and the mixture was stirred at $4^{\circ} \mathrm{C}$ for $1 \mathrm{hr}$ and poured onto a small column. The flowthrough and a $4 \mathrm{ml}$ wash were pooled, lyophylized, and redissolved in $\mathrm{H}_{2} \mathrm{O}$. The phosphorylated form of the peptide was separated from the remaining unphosphorylated peptide $(<5 \%)$ by HPLC on a preparative Vydac $C_{18}$ reverse-phase column. Elution was performed with an increasing linear gradient of solvent $\mathrm{B}\left(70 \% \mathrm{CH}_{3} \mathrm{CN}, 0.085 \%\right.$ trifluoroacetic acid in $\left.\mathrm{H}_{2} \mathrm{O}\right)$ in solvent $\mathrm{A}\left(0.1 \%\right.$ trifluoroacetic acid in $\left.\mathrm{H}_{2} \mathrm{O}\right)$ as follows: $0-3 \mathrm{~min}, 0 \% \mathrm{~B} ; 3-8 \mathrm{~min}, 0-18 \% \mathrm{~B} ; 8-40 \mathrm{~min}, 18-22 \% \mathrm{~B}$. The purified phosphopeptide was coupled to Limulus hemocyanin (Sigma), which was shown to be devoid of contaminating phosphatase activity. Coupling was carried out using $0.15 \%$ glutaraldehyde for $120 \mathrm{~min}$ at $4^{\circ} \mathrm{C}$ in $2.6 \mathrm{ml}$ of $68 \mathrm{~mm}$ sodium phosphate, $\mathrm{pH} 7.4$. The reaction was stopped by the addition of $150 \mu \mathrm{l}$ of sodium borohydride $(25 \mathrm{mg} / \mathrm{ml})$. The coupled peptide was dialyzed against two times 4 liters of a buffer

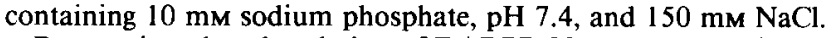

Preparative phosphorylation of DARPP-32 or $I_{1}$ was carried out in conditions similar to those described above for the peptide using lowspecific-activity $\gamma^{32} \mathrm{P}-\mathrm{ATP}(0.1 \mathrm{Ci} / \mathrm{mmol})$. The concentration of protein substrate was $10-20 \mu \mathrm{M}$, and the amount of catalytic subunit was $5 \mu \mathrm{g}$ in a final volume of $100 \mu \mathrm{l}$. Aliquots of the reaction mix were heated to $100^{\circ} \mathrm{C}$ for $1 \mathrm{~min}$ in a boiling water bath to stop the reaction and used for calculating the stoichiometry of phosphorylation. $\gamma^{32} \mathrm{P}$-phosphoDARPP-32 was separated from remaining nucleotide di- and triphosphate by anion-exchange chromatography as described for the peptides. Control dephospho-DARPP-32 or dephospho- $I_{1}$ were treated the same way except that the protein kinase was omitted from the reaction mixture.

Iodination of phospho-DARPP-32 (2.2 nmol) was carried out for 15 min at room temperature with an Iodo-Bead (Pierce) using $2.5 \mathrm{mCi}$ of ${ }^{125} \mathrm{I}-\mathrm{Nal}$ in $215 \mu \mathrm{l}$ of $90 \mathrm{~mm}$ sodium phosphate buffer, $\mathrm{pH} 7.4$. Iodinated phospho-DARPP-32 was separated from free iodine by chromatography on a $1 \times 12 \mathrm{~cm}$ column of Sephadex G-25 equilibrated in a buffer containing $100 \mathrm{~mm}$ sodium phosphate, $\mathrm{pH} 7.4,0.25 \%(\mathrm{w} / \mathrm{v})$ bovine serum albumin, and $0.1 \%(\mathrm{w} / \mathrm{v})$ sodium dodccyl sulfate.

\section{Production of monoclonal antibodies against phospho-DARPP-32 peptide}

Monoclonal antibodies were prepared against the phosphorylated peptide using the method of Kohler and Milstein (1975). The phosphopeptide conjugated to Limulus hemocyanin was used to immunize Balb/c mice. Spleen cells from mice whose serum was reactive with phosphoDARPP-32 were fused with SP $2 / 0$ mouse myeloma cells. Screening of mouse sera and fusion supernatants was first carried out using a modified ELISA. Nunc II plates (96 well, Nunc, Sweden) were coated overnight with aliquots $(1 \mu \mathrm{g} /$ well $)$ of the 10 amino acid phosphorylated peptide (conjugated to BSA) that had been used for immunization of mice. After blocking with $1 \%$ BSA in PBS, supernatants from fusion hybrids (100 $\mu$ l) were added and incubated for $30 \mathrm{~min}$ at $37^{\circ} \mathrm{C}$. The plates were washed three times with PBS containing $1 \%$ BSA and $0.1 \%$ Tween 80 . Goat 
anti-mouse IgG conjugated to horseradish peroxidase (100 $\mu$ l of a 1:100 dilution; Kirkegard and Perry, Gaithersburg, MD) was added to each well, and incubation was carried out for an additional $30 \mathrm{~min}$ at $37^{\circ} \mathrm{C}$, after which the plates were washed three times with $1 \%$ BSA and $0.1 \%$ Tween 80 . Fifty microliters of a substrate solution containing a $1: 1$ mixture of hydrogen peroxide and ABTS (2,2-amino-di[3-ethyl-benzthiazoline sulfonate]; Kirkegaard and Perry, Gaithersburg, MD) were added to each well, and the resulting color reaction was quantified after 30 min using an SLT ER400 EIA rcader (SLT Labinstruments, Austria). From approximately 2000 clones initially screened using this procedure about 500 showed positive color reactions with the phosphorylated DARPP-32 peptide and were further tested with regard to their specificity for the phospho- versus dephospho-form of the native protein. The protocol for these experiments was essentially the same as that used for the primary screening except that plates were coated with aliquots of dephosphorylated or phosphorylated DARPP-32 purified and prepared as described above. Nearly $50 \%$ of these clones reacted preferentially with the phosphorylated DARPP-32, and 27 of these were selected for further use. The antibody produced by one of these clones (mAb 23) was shown to react strongly with the phospho-form but not the dephospho-form of DARPP-32 and was further assessed by immunoprecipitation of $\gamma^{32} \mathrm{P}$-phospho-DARPP-32, as described previously (Hemmings and Greengard, 1986), and by dot-immunobinding assay. These cells were injected (intraperitoneally) into $\mathrm{Balb} / \mathrm{c}$ mice primed with pristane $(0.5 \mathrm{ml} /$ mouse). Ascites was collected from these mice for use in the present experiments and stored at $-70^{\circ} \mathrm{C}$.

\section{Immunoprecipitation of phospho-DARPP-32}

Microcentrifuge tubes containing ${ }^{125}$ I-labeled phospho-DARPP-32 (10,000 cpm/tube), 1:10 dilution of ascites, and various concentrations of an unlabeled competing antigen (dephospho-DARPP-32, phosphoDARPP-32, dephospho- $\mathrm{I}_{1}$, phospho- $\mathrm{I}_{t}$ ) were incubated for $2 \mathrm{~h}$ at $4^{\circ} \mathrm{C}$ in $0.1 \mathrm{ml}$ of NETF buffer, of the following composition $100 \mathrm{mM} \mathrm{NaCl}$, 5 mм EDTA, 50 mм Tris $\mathrm{HCl}, \mathrm{pH} 7.5,50 \mathrm{~mm}$ NaF, $1 \%$ NP-40, 100 mM phenylmethylsulfonyl fluoride (PMSF), and $1 \mathrm{mg} / \mathrm{ml} \mathrm{BSA}$. A $25 \mu \mathrm{l}$ aliquot of rabbit anti-mouse IgG was added to each tube, and these samples were incubated for an additional hour at $4^{\circ} \mathrm{C}$. A solution of Staphylcoccus aureus cells (SACs) bearing protein A (3.1 mg protein/ $\mathrm{ml}$ ) that had been washed and suspended in NETF buffer containing $25 \mathrm{mg} / \mathrm{ml} \mathrm{BSA}$ was then added ( $50 \mu \mathrm{l} / \mathrm{tube}$ ), and the tubes were incubated for a $30 \mathrm{~min}$ period at $4^{\circ} \mathrm{C}$. The tubes were centrifuged in a Beckman J-6M centrifuge at $1000 \times g$ for $15 \mathrm{~min}$. The resulting SAC pellet was washed two times with $0.1 \mathrm{ml}$ of NETF, and its radioactivity was measured using a Beckman 5500 gamma counter.

\section{In vitro phosphorylation of proteins in acid extracts}

Male Sprague-Dawley rats weighing 250-300 gm were killed by decapitation. The brains were placed on an ice-cold glass plate, and either corpus striatum or choroid plexus from lateral ventricles was dissected. Tissue was homogenized in $10 \mathrm{vol}$ of cold $5 \mathrm{~mm}$ zinc acetate and centrifuged at $3000 \times g$ for $10 \mathrm{~min}$, and the pellet was resuspended in 10 vol of $10 \mathrm{~mm}$ citric acid containing $0.1 \%$ Nonidet $P-40$. This acid extract was neutralized to $\mathrm{pH} 7.0$ by addition of 0.1 vol of $0.5 \mathrm{M} \mathrm{Na}_{2} \mathrm{HPO}_{4}$ and boiled at $95^{\circ} \mathrm{C}$ for $1 \mathrm{~min}$. This neutralized extract was centrifuged at $10,000 \times g$ for $10 \mathrm{~min}$, and the supernatant was used for in vitro phosphorylation. Phosphorylation was carried out in a buffer containing 50 mм HEPES, pH 7.4, 10 mm magnesium acetate, 1 mм EGTA, 20 $\mu \mathrm{M}$ ATP, and $1 \mu \mathrm{g} / \mathrm{ml}$ catalytic subunit of cyclic AMP-dependent protein kinase. The tubes were incubated in a shaking water bath at $30^{\circ} \mathrm{C}$ for $30 \mathrm{~min}$. The incubation was terminated by the addition of an equal volume of "sample buffer" containing $50 \mathrm{~mm}$ Tris $\mathrm{HCl}, \mathrm{pH} 6.8,10 \%$ glycerol, 2\% sodium dodecyl sulfate (SDS), 10\% 2-mercaptoethanol, and $0.01 \%$ bromophenol blue. Samples were heated at $95^{\circ} \mathrm{C}$ for $3 \mathrm{~min}$ and subjected to electrophoresis on $12 \%$ acrylamide gels (Laemmli, 1970).

In vitro phosphorylation of purified DARPP-32 and inhibitor-1

The time course of phosphorylation of DARPP-32 and $I_{1}$ by cAMPdependent protein kinase as measured by immunoblotting with $\mathrm{mAb}$ 23 was compared with the time course of phosphate incorporation from $\gamma^{32}$ P-ATP. Preparations of DARPP-32 and $\mathrm{I}_{1}(10-20 \mu \mathrm{M})$ were phosphorylated in vitro as described above. In addition, the concentration of catalytic subunit used was decreased by a factor of 1000 in order to reduce the rate of protein phosphorylation and facilitate measurement of time-dependent increases in phosphate incorporation. Parallel phosphorylation reactions were carried out in two tubes, one that received $1 \mathrm{~mm}$ unlabeled ATP and another that received $1 \mathrm{~mm} \gamma^{32}$ P-ATP (2 $\mathrm{mCi} / \mathrm{ml}$ ). Both tubes were incubated for $60 \mathrm{~min}$. At $2.5,5,7.5,10,15$, 30,45 , and $60 \mathrm{~min}$, a $10 \mu \mathrm{l}$ aliquot of the phosphorylation mix was removed from each tube, added to a $50 \mu \mathrm{l}$ aliquot of sample buffer, and boiled for $3 \mathrm{~min}$ at $95^{\circ} \mathrm{C}$. Proteins were separated by SDS-PAGE on a $12 \%$ acrylamide gel.

\section{Immunoblotting}

Electrophoretic transfer of proteins from polyacrylamide gels to nitrocellulose membranes was carried out according to Towbin et al. (1979). Dot blots were prepared by spotting $1 \mu \mathrm{l}$ of phospho- or dephosphoDARPP-32 at concentrations ranging from 1 to $100 \mu \mathrm{g} / \mathrm{ml}$ on nitrocellulose strips. Proteins were fixed by a $10 \mathrm{~min}$ incubation in $25 \%$ isopropanol and $10 \%$ glacial acetic acid. Immunolabeling was performed as described for DARPP-32 and $I_{1}$ (Girault et al., 1989). Labeling of the antibodies was achieved by incubating the membranes sequentially in affinity-purified rabbit anti-mouse IgG (1:500, Cappell, when a mouse primary antibody was used) and ${ }^{125} I$-iodo-protein $A$ as described previously (Girault et al., 1989).

\section{Preparation and treatment of striatal reaggregate cultures}

Striatal reaggregate cultures were prepared from embryonic day $14 \mathrm{CD}-1$ mousc cmbryos as described previously (Hcmmendinger et al., 1981) with a few modifications (Girault et al., 1988). Three-week-old reaggregate cultures were incubated for $1 \mathrm{hr}$ in modified Krebs' buffer and further incubated in the presence or absence of forskolin as described previously (Girault et al., 1988). Incubations were stopped by aspiration of the buffer and immersing the tubes containing the aggregates in liquid nitrogen. Cells were stored at $-70^{\circ} \mathrm{C}$ until analysis. Reaggregates were homogenized by sonication in $1 \%$ boiling SDS and placed for an additional $10 \mathrm{~min}$ in a protein boiling water bath. Equal amounts of protein $(150-350 \mu \mathrm{g})$ in sample buffer were subjected to SDS-PAGE and immunoblotting as described above.

\section{Pharmacological treatment of rat choroid plexus}

Rats were decapitated, and choroid plexus was dissected from the lateral cerebral ventricles. Choroid plexus from five rats per treatment condition were incubated in $25 \mathrm{ml}$ Ehrlenmeyer flasks containing $20 \mathrm{ml}$ of oxygenated RPMI 1640 medium in a shaking water bath $\left(30^{\circ} \mathrm{C}\right)$. After a 45 min preincubation period, medium was replaced with fresh normal RPMI 1640 or medium containing drug, and the tissue was incubated for an additional 5-45 min. After drug treatment, choroid plexuses were rapidly transferred to glass tubes using a Pasteur pipette and homogenized in $5 \mathrm{vol}$ of cold $5 \mathrm{~mm}$ zinc acetate. The tissue was acid extracted and proteins separated by SDS-PAGE as described above (In vitro phosphorylation of proteins in acid extracts). In addition, a $0.5 \mathrm{ml}$ aliquot of the incubation medium and a $0.1 \mathrm{ml}$ aliquot of the zinc acetate homogenate were retained from control and drug-treated tissue, acidified with an equal volume of $0.2 \mathrm{~N} \mathrm{HCl}$, and used for cyclic AMP determinations using the method of Brooker et al. (1976).

\section{Immunohistochemical identification and localization of DARPP-32, $I_{1}$, and Na,K-ATPase in rat choroid plexus}

Intact tissue. Intact lateral and fourth ventricular choroid plexuses from 8-week-old male Sprague-Dawley rats were dissected in Dulbecco's modified Eagle's medium (DMEM) and meticulously cleaned of any adhering meninges or brain under a high-power dissecting scope. Samples of lateral and fourth ventricular choroid were cut into $2-4 \mathrm{~mm}$ pieces, fixed for $1 \mathrm{hr}$ in $1.5 \%$ or $2 \%$ paraformaldehyde, washed twice for $5 \mathrm{~min}$ in phosphate-buffered normal saline (PBS), and then stored at $0^{\circ} \mathrm{C}$. Prior to immunostaining, the picces of choroid were transferred to albumin-coated slides and air dried.

Epithelial and vascular cell fractions. Choroid epithelium was isolated and separated from choroid stroma as described previously (Nathanson, 1980; Nathanson and Chun, 1989). Briefly, pooled choroid plexuses (above) were further washed $(3 \times 10 \mathrm{~min})$ in $10 \mathrm{ml}$ of DMEM by gently tumbling $(90 \mathrm{rpm})$ in a Rotovapor apparatus (in a $100 \mathrm{ml}$ spherical flask), which allowed suspended cells to be separated and removed from intact tissue. Subsequently, tissue was tumbled in calcium-free artificial 


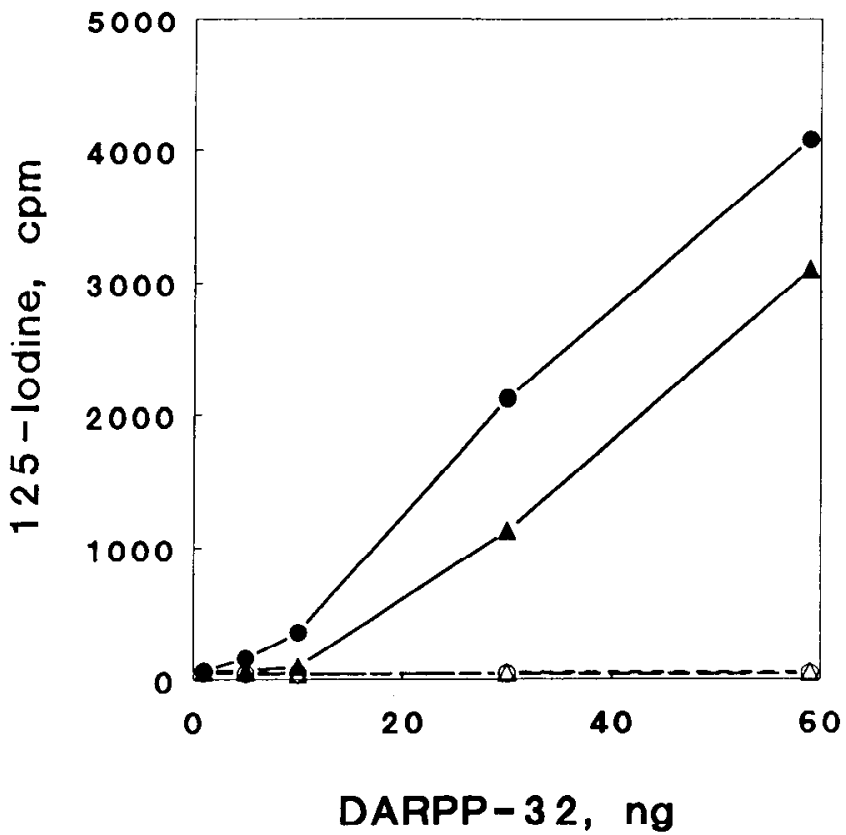

Figure 2. $\mathrm{mAb} 23$ detected increasing quantities of phospho-DARPP. 32 but not dephospho-DARPP-32 in dot blot analysis. Various amounts of phosphorylated (solid symbols) or dephosphorylated (open symbols) purified DARPP-32 were spotted on nitrocellulose strips and detected by incubation with various dilutions of $\mathrm{mAb} 23$ (triangles, 1:50,000; circles, 1:5000). Antibody binding was determined by sequential incubation with rabbit anti-mouse IgG (1:500 dilution) and ${ }^{125}$ I-iodo-protein A (1:1000 dilution) and was quantitated by gamma radiation counting. Each point represents the mean of triplicate determinations.

CSF (Nathanson, 1980) containing 0.05\% trypsin (Sigma) and $15 \mu \mathrm{M}$ EDTA. Every $15 \mathrm{~min}$ for $4 \mathrm{hr}$, choroid plexuses were gently triturated and allowed to settle, and supernatant fractions containing suspended cells were removed from intact tissue; in this manner, a large peak of highly enriched epithelial cells was obtained (usually fractions 5-10), prior to the onset of dissociation of the choroid plexus stroma (usually fractions 11-15). Cells from pooled fractions 5-10 were filtered through $150 \mu \mathrm{m}$ Nitex mesh to remove large cell aggregates, centrifuged and washed at low speed with PBS, and then fixed in $1.5 \%$ or $2 \%$ paraformaldehyde for $1 \mathrm{hr}$. Following two washes with PBS, approximately 1$5 \times 10^{4}$ cells were air dried on albumin-coated slides. The remaining, largely deepithelialized and fragmented choroid plexus present in the original dissociating flask were washed with PBS and fixed as above, and then aliquots were air dried on albumin-coated slides.

For pharmacological studies of cyclic nucleotide accumulation in isolated choroid epithelium, cells, isolated as above, were preincubated for 60 min at $34^{\circ} \mathrm{C}$ in DMEM containing $40 \mathrm{~mm}$ HEPES under $95 \% \mathrm{O}_{2}$, $5 \% \mathrm{CO}_{2}$. Aliquots of $1 \times 10^{5}$ cells were then transferred to tubes containing $0.2 \mathrm{ml}$ of artificial CSF (Nathanson, 1980) supplemented with $0.1 \%$ bovine serum albumin and $2.5 \mathrm{~mm}$ ascorbic acid. Either dopamine $(100 \mu \mathrm{M})$ or ANF $(1 \mu \mathrm{M})$ was added, and cells were incubated for $3 \mathrm{~min}$, following which an equal volume of $150 \mathrm{~mm}$ sodium acetate was added and the tubes heated to $90^{\circ} \mathrm{C}$ for $3 \mathrm{~min}$. Tubes were then centrifuged, and cAMP and cGMP levels were determined in the supernatant by radioimmunoassay (Du Pont).

Immunostaining. Air-dried slides of whole choroid or choroid cell fractions were washed three times with PBS and once (for $10 \mathrm{~min}$ ) with $4 \%$ goat serum, and incubated overnight at $4{ }^{\circ} \mathrm{C}$ with rabbit polyclonal antibody (K2,1:150) to the $\alpha$-form of Na,K-ATPase, with mouse monoclonal antibody $(1: 300)$ to DARPP-32, or with rabbit polyclonal antiserum $(G 187,1: 50-1: 150)$ to $I_{1}$ diluted in $0.1 \%$ Triton $X-100$ and $4 \%$ goat serum in PBS. Following five washes with PBS, slides were incubated for $1 \mathrm{hr}$ at room temperature with the appropriate fluorescein- or rhodamine-labeled goat secondary antibody $\left[\mathrm{F}\left(\mathrm{ab}^{\prime}\right)_{2}\right.$ fragment] (Cappel Labs, 1:100 dilution), washed five times with PBS, mounted in 67\% glycerol containing $0.67 \%$ propyl gallate, and viewed by epifluorescence with an inverted microscope.

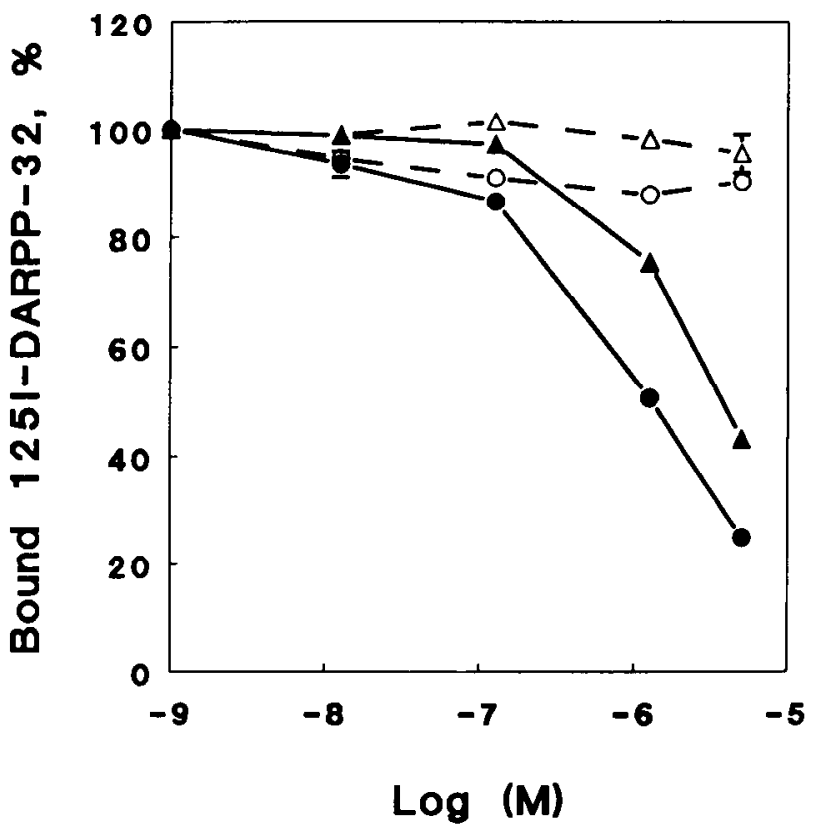

Figure 3. Immunoprecipitation of ${ }^{125}$ I-labeled phospho-DARPP-32 by $\mathrm{mAb} 23$ was competitively inhibited by the phospho- but not the dephospho-form of DARPP-32 or $I_{1}$. ${ }^{125}$ I-iodo-phospho-DARPP-32 was incubated with $\mathrm{mAb} 23$ (1:10 dilution) in the absence or presence of the phospho- (solid symbols) or dephospho- (open symbols) forms of either DARPP-32 (circles) or $\mathbf{I}_{1}$ (triangles). Bound antigen was precipitated by sequential incubation with rabbit anti-mouse IgG and SACs bearing protein $\mathrm{A}$. The amount of labeled antigen precipitated by antibody under each condition was quantitated by counting radioactivity of the SAC pellet. Under these conditions, approximately $60 \%$ of the labeled antigen was precipitated in the absence of competing antigens. All data are expressed as a mean percentage of this value \pm SEM of three determinations; when not apparent on the figure, SEM values were smaller than the size of the symbol).

Miscellaneous methods. Autoradiography was performed using Kodak XAR-5 film at room temperature or at $-70^{\circ} \mathrm{C}$ with Du Pont Quanta II intensifying screens. Amounts of ${ }^{125}$ I-iodo-protein A bound to the antigen on nitrocellulose filters, or of $\gamma^{32} \mathrm{P}$-phosphate incorporated into proteins, were determined by excising the radioactive bands using autoradiograms as guides. ${ }^{125}$ I-iodine was then measured in a gamma counter, and $\gamma^{32} \mathrm{P}$-phosphate was quantified by scintillation spectrometry or by determination of Cerenkov radiation. Data were analyzed by ANOVA (for post hoc comparisons), with significance defined as $p<$ 0.05 . Protein concentrations were measured by the bicinchoninic acid method (Smith et al., 1985) or by the method of Lowry et al. (1951), using bovine serum albumin as a standard.

\section{Results}

In vitro characterization of a monoclonal antibody specific for DARPP-32 phosphorylated by cAMP-dependent protein kinase. In dot-immunobinding assays, mAb 23 reacted with phosphoDARPP-32, but not dephospho-DARPP-32 (Fig. 2). The ability of this antibody to distinguish between phospho- and dephospho- forms of DARPP-32 was demonstrated further by competitive immunoprecipitation experiments in which precipitation of holo-125I-iodo-phospho-DARPP-32 was inhibited effectively by unlabeled phosphorylated DARPP-32, but not dephosphorylated DARPP-32 (Fig. 3). Because of the similar primary sequences surrounding the cAMP-dependent phosphorylation sites of DARPP-32 and $I_{1}$, the precipitation of radiolabeled substrate also was inhibited competitively by phosphorylated $I_{1}$ in a concentration-dependent manner (Fig. 3). 
A.

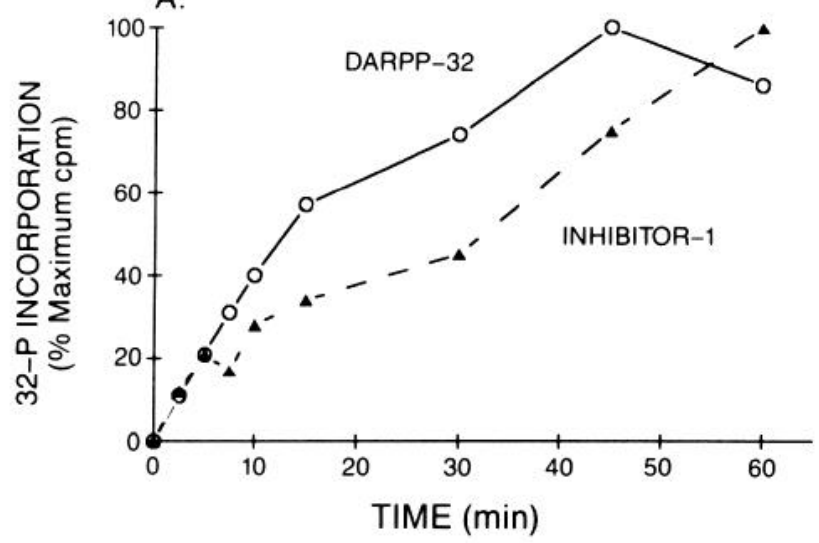

B.

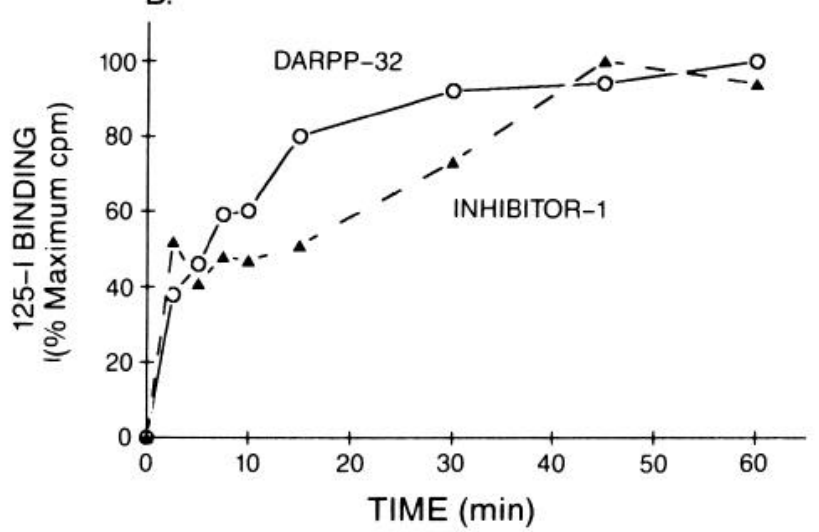

Figure 4. Time course of DARPP-32 and $\mathrm{I}_{1}$ phosphorylation measured by $\gamma^{32} \mathrm{P}$-incorporation $(A)$ or immunoblotting with $\mathrm{mAb} 23(B)$. Purified preparations of DARPP-32 (open symbols) or $\mathrm{I}_{1}$ (solid symbols) were phosphorylated in vitro in the presence of catalytic subunit of cAMPdependent protein kinase and either $\gamma^{32}$ P-ATP $(A)$ or cold ATP $(B)$. Aliquots of these reaction mixtures were withdrawn at various times and subjected to SDS-PAGE. Gels containing samples phosphorylated with radiolabeled phosphate were directly autoradiographed. Proteins phosphorylated in parallel experiments using cold ATP were transferred to nitrocellulose membranes and immunoblotted using mAb 23, rabbit anti-mouse IgG (1:500 dilution), and ${ }^{125}$ I-iodo-protein A (1:1000 dilution). Radioactivity was counted in excised segments of gel ( $\gamma^{32}$ phosphate) or nitrocellulose membranes ('25iodine) in order to quantitate phosphate content of proteins at each time point.

Dephospho- $\mathrm{I}_{1}$, like dephospho-DARPP-32, had no significant effect on the immunoprecipitation of ${ }^{125}$ I-iodo-phospho-DARPP32 by mAb 23 (Fig. 3).

The correlation between DARPP-32 phosphorylation and the detection of the protein by $\mathrm{mAb} 23$ was examined by following the time course of DARPP-32 phosphorylation in the presence of cAMP-dependent protein kinase (Fig. 4). The $\gamma^{32} \mathrm{P}$-phosphate content of DARPP-32 increased rapidly within the initial 15 min of exposure to the kinase, as did the immunoreactivity of the protein toward $\mathrm{mAb} 23$. Under the same conditions, $I_{1}$ was phosphorylated at a slower rate than DARPP-32 as indicated both by phosphate content and immunoreactivity of the protein.

Further characterization of the phospho-DARPP-32 antibody using striatal extracts and striatal reaggregate cultures. The usefulness of mAb 23 for detection of phosphorylated DARPP-32 in brain and peripheral tissues first was assessed using striatum, a brain region in which DARPP-32 is highly enriched (Hemmings and Greengard, 1986). An immunoreactive band with an

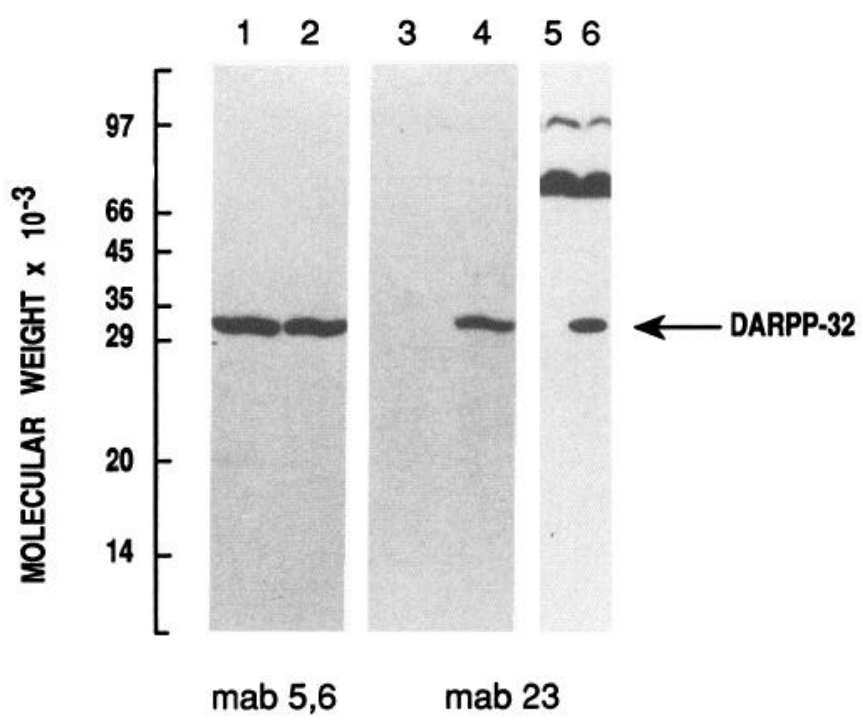

Figure 5. DARPP-32 and phospho-DARPP-32 were detected in phosphorylated acid extracts of rat striatum and in striatal reaggregate cultures treated with forskolin. Acid extracts of rat striatum were phosphorylated by incubation with the catalytic subunit of cAMP-dependent protein kinase for $30 \mathrm{~min}$ (lanes 2 and 4), or were incubated for $30 \mathrm{~min}$ without addition of the protein kinase (lanes 1 and 3), a treatment that promotes dephosphorylation of DARPP-32. Proteins were separated by SDS-PAGE (70 $\mu$ g protein/lane), transferred to nitrocellulose, and immunoblotted as described in the Figure 4 caption using as the primary antibody either a mixture of the DARPP-32 monoclonal antibody C24$6 \mathrm{~A}$ and $-5 \mathrm{~A}$ ( $m A b 5,6 ; 1: 1000$ dilution; lanes $I$ and 2$)$ or ( $\mathrm{mAb} \mathrm{23}$; 1:100 dilution; lanes 3 and 4). Striatal cultures were prepared from embryonic mouse striatum as described in Materials and Methods. Three week aggregate cultures were incubated for $6 \mathrm{~min}$ in the absence (lane 5) or presence (lane 6 ) of forskolin $(50 \mu \mathrm{M})$ in physiological buffer at $37^{\circ} \mathrm{C}$. Incubations were stopped by freezing in liquid nitrogen. Cells were homogenized by sonication in $1 \%(\mathrm{w} / \mathrm{v})$ hot SDS containing $5 \mathrm{~mm}$ zinc acetate and maintained for $5 \mathrm{~min}$ in a boiling water bath. Equal amounts of protein $(270 \mu \mathrm{g})$ were loaded on SDS-polyacrylamide gels, separated by electrophoresis, transferred to nitrocellulose and immunoblotted with mAb 23 as described above. Antibodies were detected by ${ }^{125}$ I-iodoprotein $A$ overlay and autoradiography. In addition to phospho-DARPP-32 (arrow), the mAb 23 antibodies also reacted with unidentified bands of higher molecular weight that were apparent only in the SDS homogenates and not acid extracts phosphorylated in vitro with catalytic subunit of the cAMP-dependent protein kinase. The immunoreactivity of these bands with $\mathrm{mAb} 23$ was not altered by forskolin.

apparent $M_{r}$ of $\sim 34,000$ was revealed by this antibody in acid extracts of adult rat striatum that had been phosphorylated in vitro with catalytic subunit of cAMP-dependent protein kinase (Fig. 5, lane 4), but not in extracts incubated in the absence of the kinase (Fig. 5, lane 3). This protein band was identified as DARPP-32 using a mixture of C24-6A and -5A monoclonal antibodies (mAb 5,6, Fig. 5, lanes 1, 2).

A comparable protein band was revealed in SDS homogenates prepared from 3-week-old striatal aggregate cultures that had been incubated for $6 \mathrm{~min}$ in the presence of forskolin $(50 \mu \mathrm{M})$, a drug known to stimulate cAMP formation (see Seamon and Daly, 1986) and thereby activate endogenous cAMP-dependent protein kinase. Forskolin treatment increased phospho-DARPP32 immunoreactivity in striatal cells (Fig. 5, lane 6), whereas no detectable immunoreactivity was present in homogenates from untreated striatal cultures (Fig. 5, lane 5). Additional immunoreactive bands with apparent $M_{r} \sim 75,000$ and $\sim 100,000$ were observed. These immunoreactive bands were also found 

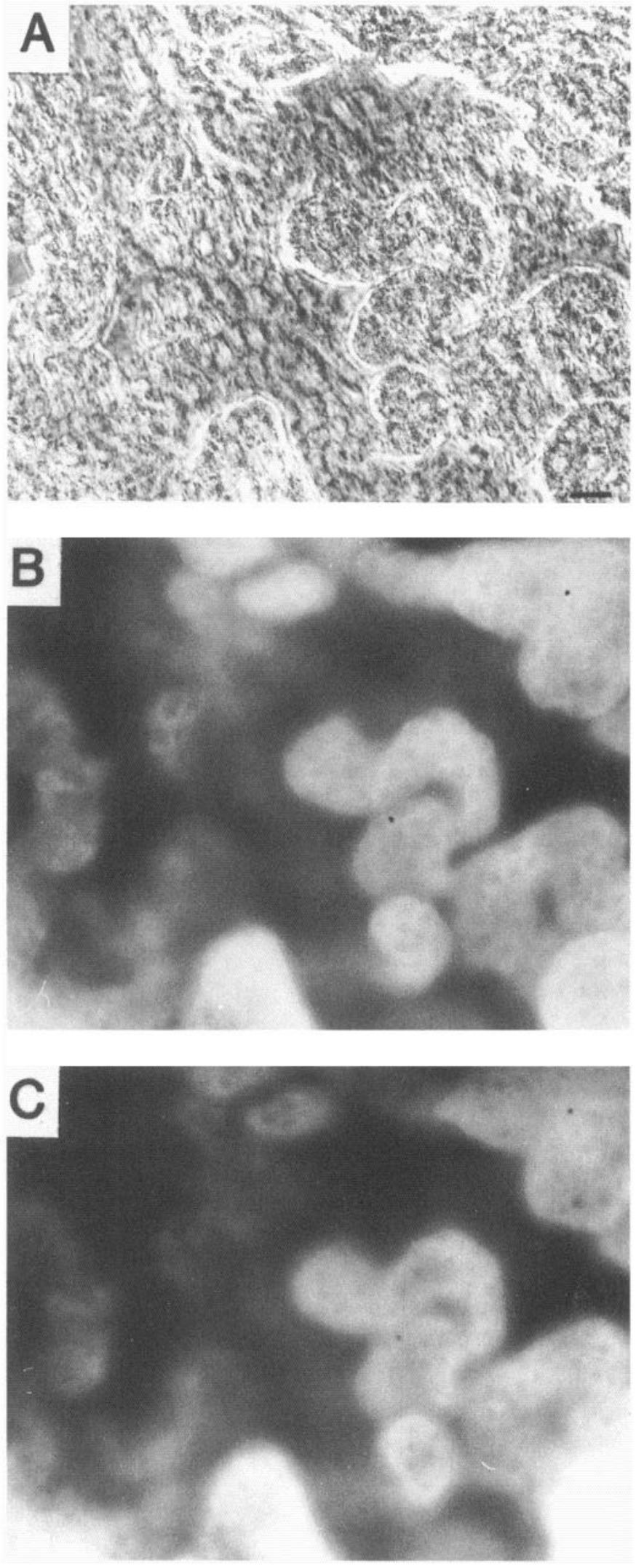

Figure 6. DARPP-32 immunostaining in whole-mount of rat choroid plexus. Whole-mount of tissue slice of rat choroid plexus from lateral ventricle shown by phase contrast $(A)$; by fluorescein optics, immunostained for DARPP-32 $(B)$; and by rhodamine optics, immunostained for $\mathrm{Na}, \mathrm{K}-\mathrm{ATPase}(C)$. Note presence and localization of DARPP-32 immunoreactivity in choroid plexus villae, which are covered with CSF- in tissues from adult rat (data not shown). However, these protein bands were not affected by forskolin treatment, and were not recognized by other antibodies specific for DARPP-32 or $I_{1}$ (Fig. 5, and data not shown; see also below).

Immunohistochemistry of DARPP-32 and $I_{1}$ in rat choroid plexus. The increased formation of cAMP observed in choroid plexus in response to pharmacological treatment of this tissue occurs primarily in the epithelial cells (Nathanson, 1980). In the present studies, we examined whether DARPP-32 and $I_{1}$ were localized to this cell type. Tissue slices of rat choroid plexus from both lateral and fourth ventricle showed bright immunoreactive staining for DARPP-32. Figure 6 shows an example of lateral ventricular choroid that consists of numerous epithelial-covered capillary loops (villae) arising from a veil-like ependymal membrane that floats within the ventricle. These can be visualized by phase contrast in Figure $6 A$, but are much more easily seen in Figure $6 \mathrm{~B}$, which shows that the bright immunoreactive staining for DARPP-32 is localized primarily to the thicker epithelial-covered loops. Other loops, below the plane of focus, appear fainter. Staining was brightest in epithelial cells, the nuclei of which were unstained (Fig. $6 \mathrm{~B}$ ). The pattern of staining for the al (kidney) form of $\mathrm{Na}, \mathrm{K}$-ATPase, an enzyme known to be present in very high concentration in choroid plexus and other transporting epithelium (Milhorat, 1976; Sweadner and Gilkeson, 1985; Nathanson and Chun, 1989), was nearly identical to that seen for DARPP-32 (Fig. $6 \mathrm{C}$ ).

Choroid plexus from the lateral and fourth ventricles was subjected to cell separation to produce two fractions: (1) a purified preparation of epithelial cells (Fig. $7 C-F$ ), and (2) a largely deepithelialized vascular fraction consisting of collapsed capillaries, arterioles, and stroma (Fig. $7 A, B$ ). The absence of staining of the latter fraction demonstrates the selective localization of DARPP-32 to choroidal epithelium. As shown in Figure $7 \mathrm{~A}$ (phase), a few typical large, round epithelial cells remained attached to the vascular choroidal surface following cell isolation. In Figure $7 B$, these, but not the remainder of the choroid, stain brightly for DARPP-32. Cells from the epithelial cell fraction (Fig. $7 C, D$ ) demonstrate bright immunoreactive staining both for Na,K-ATPase (Fig. 7C) and DARPP-32 (Fig. 7D). Figure $7 E$ (phase) shows another group of isolated epithelial cells, used as a staining control, in which nonimmune mouse serum was substituted for the mouse monoclonal DARPP-32 antibodies. No secondary antibody immunofluorescence was observed (Fig. $7 F)$.

The immunohistochemical localization of $I_{1}$ is shown in Figure 8 . Figure $8 A$ shows by phase contrast a fragment of fourth ventricle choroid plexus, which, in one area (arrows), has been partially deepithelialized by treatment with trypsin, exposing capillaries underneath. Antiserum to $I_{1}$ results in bright staining of the epithelium (Fig. $8 B$ ) but not the deepithelialized area. Figure $8 C$ is a control section of isolated epithelial cells, in which nonimmune rabbit serum was substituted for the rabbit antiserum against $I_{1}$. No immunofluorescence is observed. Figure $8 D$ shows, by phase contrast, another piece of choroid plexus from the lateral ventricle that has also been deepithelialized in some areas (thin arrows). In most other areas, the epithelium remains intact and some detached epithelial cells (thick arrows)

secreting epithelial cells known to contain high concentrations of $\mathrm{Na}, \mathrm{K}$ ATPase. See Results for details. Scale bar, $30 \mu \mathrm{m}$. 

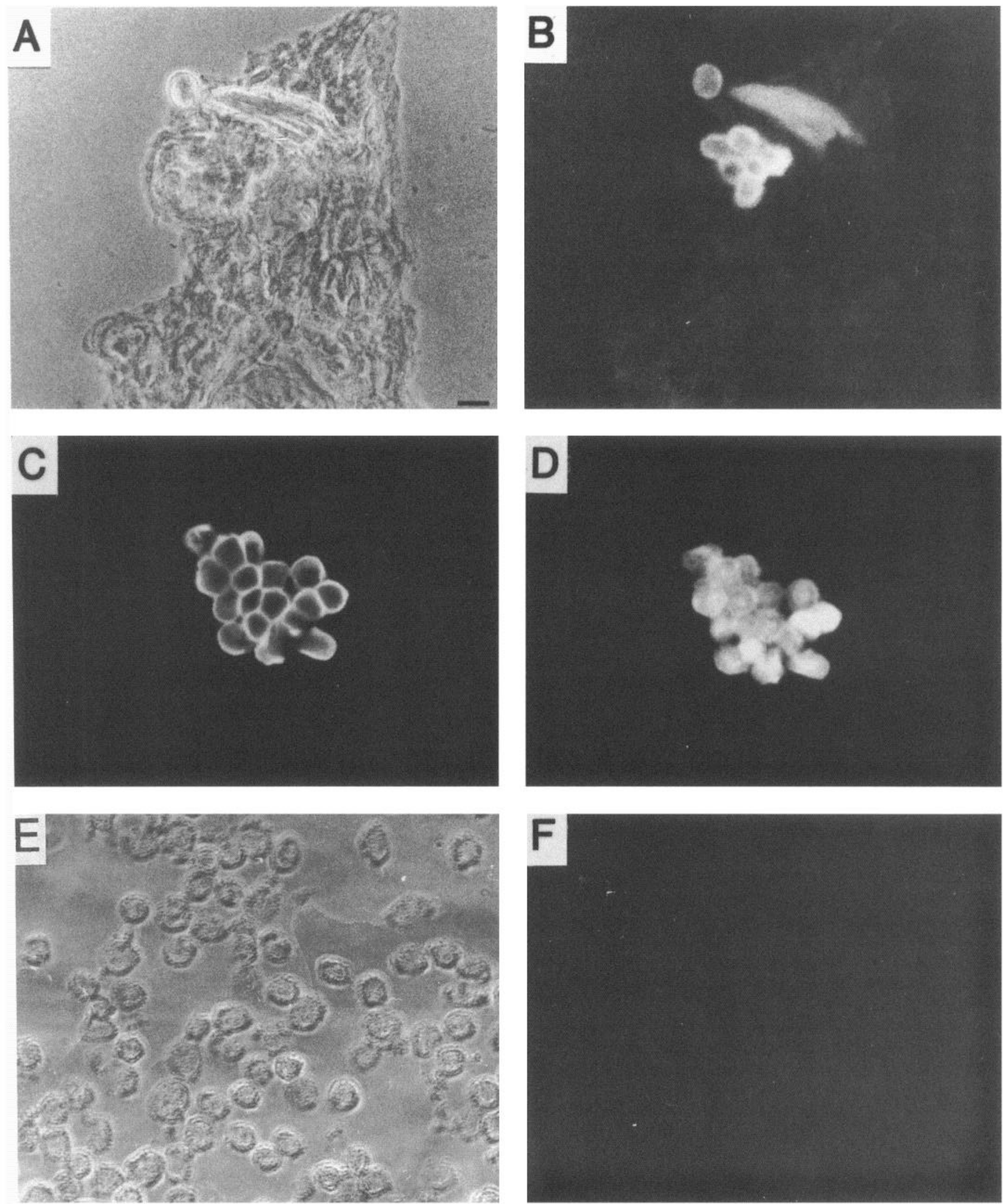

Figure 7. Isolated cell and tissue preparations from choroid plexus showing localization of immunostaining for DARPP-32 in secretory epithelial cells. $A$, As viewed by phase contrast, a piece of choroid plexus vascular stroma is almost entirely denuded of epithelium except for a few epithelial cells (barely visible) above and slightly to left of center. $B$, The same tissue, seen by fluorescein optics, shows bright immunostaining of DARPP32 in the adhering epithelial cells. The vascular and connective tissue portion of choroid shows little staining. Area of comet-shaped staining is due to autofluorescence. $C$ and $D$, A group of isolated choroid epithelial cells immunostained for Na,K-ATPase $(C)$ and the same group of cells double-labeled for DARPP-32 (D), showing that all of these cells colabel for the phosphoprotein. $E$ and $F$, A control group of isolated epithelial cells (phase; $E$ ), showing a lack of immunostaining when nonimmune serum is substituted for specific antibody $(F)$. Scale bar, $20 \mu \mathrm{m}$. 

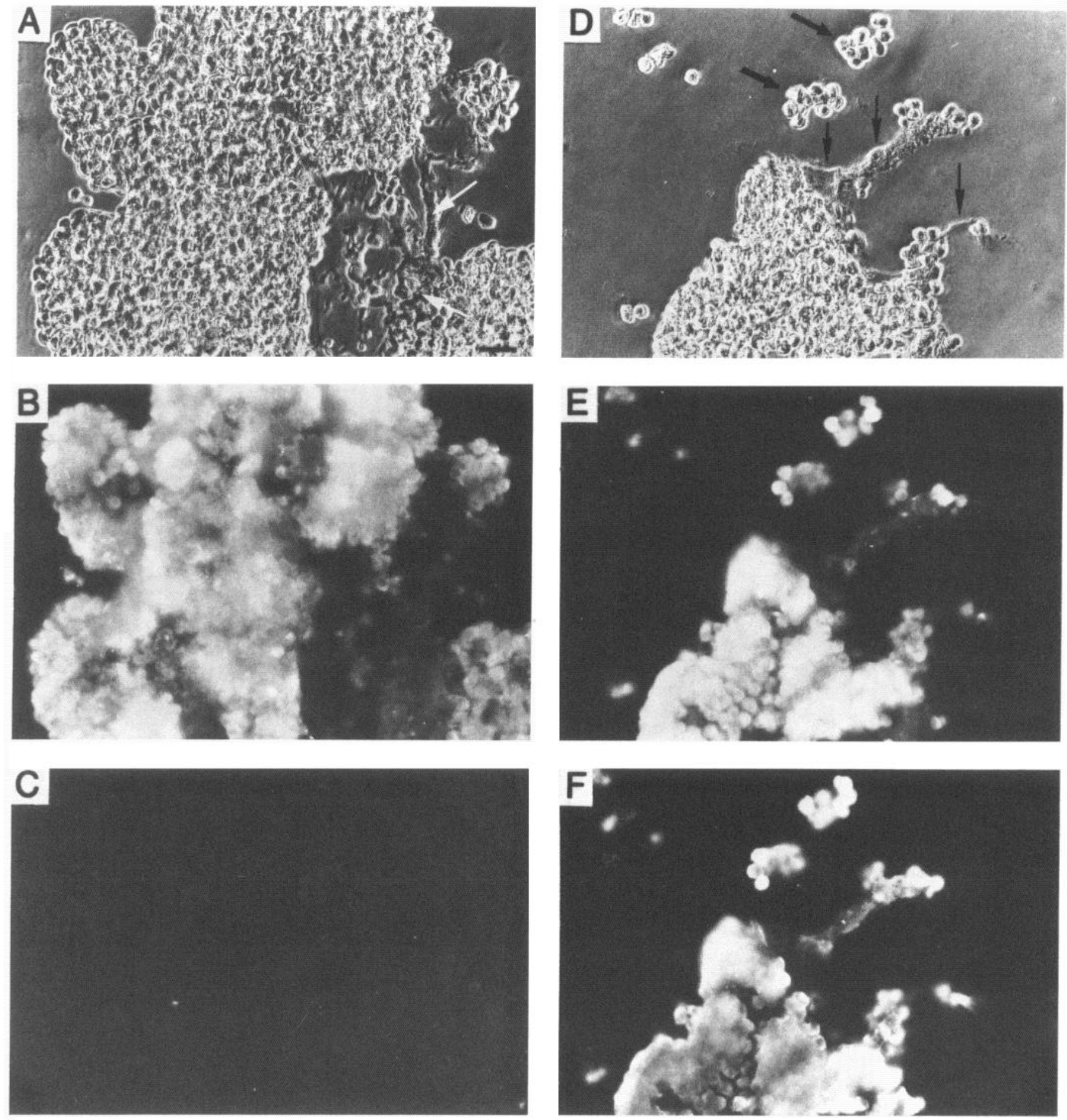

Figure 8. Choroid plexus preparations showing localization of $\mathrm{I}_{1}$ immunoreactivity to secretory epithelial cells. $A$ and $D$, Phase-contrast views of partially deepithelialized pieces of choroid plexus from fourth $(A)$ and lateral $(D)$ rat ventricle, showing areas of underlying capillaries $($ thin arrows in $A$ and $D$ ) and free dissociated epithelial cells (thick arrows in $D$ ). $B$ and $E$, The same pieces of tissue viewed by fluorescein optics show bright immunostaining for $\mathrm{I}_{1}$ in the epithelium. Capillaries show little staining. $F$. Same tissue as in $E$, seen by rhodamine optics, immunostained for DARPP-32 showing similar distribution of DARPP-32 immunoreactivity. $C$, Seen by fluorescein optics, a control group of isolated epithelial cells shows a lack of immunostaining for $I_{1}$ when nonimmune serum was substituted for specific antibody. Scale bar, $80 \mu \mathrm{m}$.

can be seen free above the piece. Figure $8 E$ shows that antiserum to $I_{1}$ immunostains the intact epithelium and free epithelial cells, with little or no localization to blood vessels. In Figure $8 F$, the same piece of choroid has been colabeled for DARPP-32, showing a similar distribution of staining intensity. It is important to note that the DARPP-32 antibodies used for immunohistochemistry showed little (1:3000) cross-reactivity with $I_{1}$. Likewise, the G-187 antibody used for histochemistry of $I_{1}$ showed no cross-reactivity to DARPP-32 (see Fig. 9). In this slide, one of the capillaries shows some immunoreactivity to DARPP-32, 


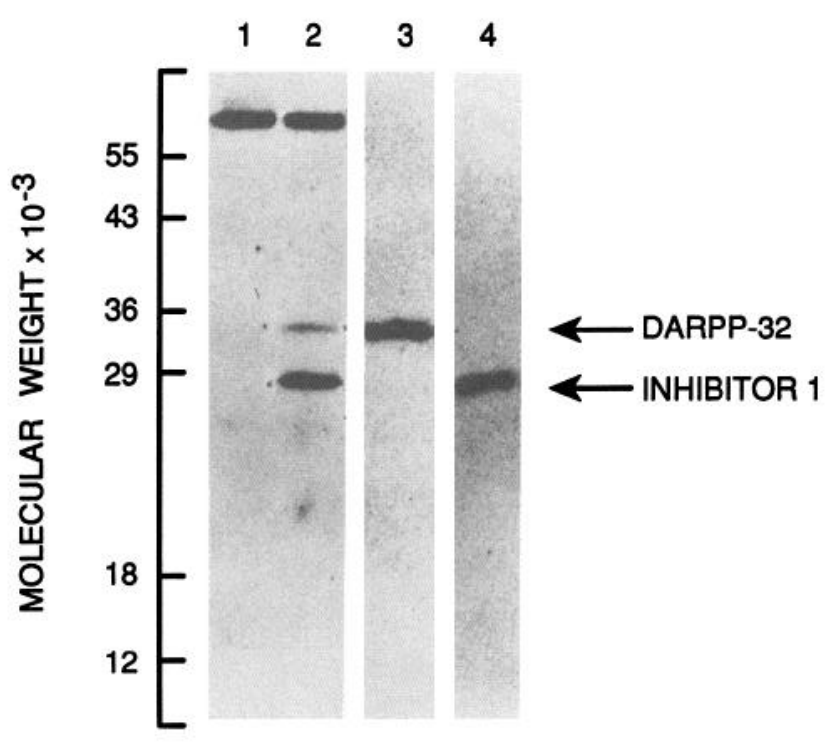

Figure 9. Forskolin stimulated an increase in phospho-DARPP-32 and phospho- $\mathrm{I}_{1}$ in rat choroid plexus. Acid extracts of untreated (lane I) or forskolin-treated (lane 2) choroid plexus were subjected to SDSPAGE ( $100 \mu \mathrm{g}$ total protein/lane) and immunoblotting on nitrocellulose membrane with $\mathrm{mAb} 23$ revealing protein bands of apparent $M_{r} \sim 29,000$ and $\sim 34,000$ only in forskolin-incubated tissue. The upper band was identified as DARPP-32 (lane 3) using the selective DARPP-32 antibody C24-4D7, which does not cross-react with $\mathrm{I}_{1}$. The lower band was identified as $I_{1}$ (lane 4), using a selective rabbit antiserum, G-187. Note that $\mathrm{mAb} 23$ detected an additional band $\left(M_{r} \sim 70,000\right)$ that was unaltered by forskolin treatment, similar to a band detected by this antibody in SDS-homogenized striatal cell aggregates (see Fig. 5).

although in most instances (e.g., Fig. 7B) choroid vascular fractions did not stain with DARPP-32 immunoreactivity.

Phosphorylation of DARPP-32 and I, in rat choroid plexus. Two bands of $M_{r} \sim 29,000$ and $\sim 34,000$ were detected by $\mathrm{mAb}$ 23 in acid extracts from whole rat choroid plexus that had been incubated in vitro with forskolin $(10 \mu \mathrm{M})$ but not in extracts prepared from untreated choroid plexus (Fig. 9, lanes 1, 2). These two bands were identified as DARPP-32 $\left(M_{r} \sim 34,000\right)$ and $\mathrm{I}_{1}\left(M_{r} \sim 29,000\right)$ using either a monoclonal antibody (C244D7) that reacts specifically with DARPP-32 (Fig. 9, lane 3) or a rabbit antiserum (G-187) that detects specifically $I_{1}$ (Fig. 9, lane 4). Forskolin markedly stimulated cAMP accumulation in extirpated choroid plexus (Fig. 10). The forskolin-stimulated phosphorylation (Figs. 9, 10) appeared within 5 min but was undetectable $30-45 \mathrm{~min}$ after drug treatment (data not shown). A protein band of apparent $M_{r} \sim 70,000$ also was revealed by mAb 23 in acid extracts of choroid plexus (Fig. 9, lanes 1, 2). Like the cross-reactive band of comparable molecular weight found in striatum, this band was not apparently regulated by forskolin (Fig. 9, lanes 1,2), nor was it detected by other DARPP32- and $\mathrm{I}_{1}$-selective antibodies (Fig. 9, lanes 3, 4, respectively).

Isoproterenol, a $\beta$-adrenergic agonist $(10 \mu \mathrm{M})$, and VIP $(1 \mu \mathrm{M})$ stimulated phosphorylation of $\mathrm{I}_{1}$ and DARPP-32 (Fig. 10). These drugs also elevated cAMP levels in choroid plexus, an observation that is consistent with the previously reported effects of these treatments on cAMP accumulation in bovine, cat, and rabbit choroid plexus (see Nathanson, 1979, 1980; Crook et al., 1984; Crook and Prusiner, 1986). Propranolol ( $10 \mu \mathrm{M})$, a $\beta$-adrenergic antagonist, blocked both the rise in cAMP levels and the increased phosphorylation of DARPP-32 and $\mathrm{I}_{1}$ produced by isoproterenol. Dopamine $(10 \mu \mathrm{M})$ failed to elevate cAMP

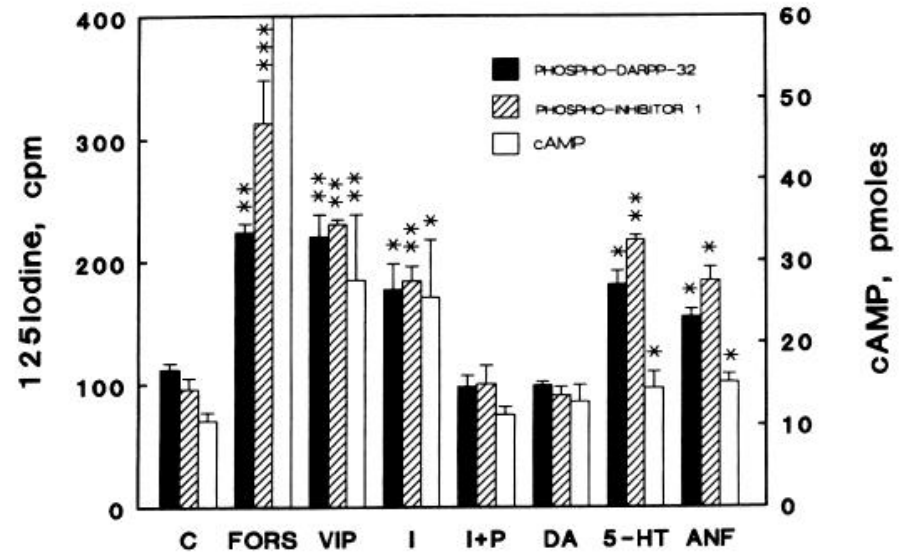

Figure 10. Levels of phospho-forms of DARPP-32 (solid bars) and $\mathrm{I}_{1}$ (hatched bars) and of cAMP (open bars) in tissue extracts prepared from rat choroid plexus incubated for $10 \mathrm{~min}$ in the absence (control) or presence of drugs. Control and drug-treated choroid plexus (lateral ventricle tissue from five rats/condition) were acid extracted and subjected to SDS-PAGE, and the proteins were transferred to nitrocellulose and immunoblotted as described in Materials and Methods. Nitrocellulose pieces identified by autoradiography were excised and their radioactivity measured to provide a quantitative measure of antibody binding. These data are expressed as mean cpm \pm SEM per band. Background levels averaged $99 \pm 7 \mathrm{cpm}$ per band. CAMP was measured in aliquots $(0.1$ $\mathrm{ml}$ ) of choroid plexus homogenized in zinc acetate buffer, and results are expressed as picomoles of cAMP (mean \pm SEM). Means correspond to the results of four to eight experiments. Means were different from antibody binding or cAMP levels in control extracts: ${ }^{*}, p<0.05$; ${ }^{* *}, p$ $<0.01 ;{ }^{* * *}, p<0.001$, ANOVA (post hoc comparisons). The cAMP increase following forskolin treatment was $262 \pm 64 \mathrm{pmol}$. $C$, Control; FORS, $10 \mu \mathrm{M}$ forskolin; VIP, $1 \mu \mathrm{M}$ VIP; $I, 10 \mu \mathrm{M}$ isoproterenol; $P, 10$ $\mu \mathrm{M}$ propranolol; $D A, 10 \mu \mathrm{M}$ dopamine; $5-H T, 10 \mu \mathrm{M}$ 5-HT; $A N F, 1 \mu \mathrm{M}$ ANF.

levels significantly in choroid plexus and produced no detectable changes in DARPP-32 or $I_{1}$ phosphorylation in this tissue. Incubation of choroid plexus with 5-HT $(10 \mu \mathrm{M})$ increased the phosphorylation state of both DARPP-32 and $\mathrm{I}_{1}$. 5-HT also produced a small, but statistically insignificant, rise in cAMP levels in choroid plexus (Fig. 10).

DARPP-32 and $I_{1}$ are phosphorylated in vitro by cGMPdependent protein kinase on the same threonyl residue phosphorylated by cAMP-dependent protein kinase (Hemmings et al., 1984b). Choroid plexus epithelial cells express relatively high concentrations of cGMP and cGMP-dependent protein kinase (Cumming et al., 1981). Since ANF has been shown to stimulate cGMP formation in these cells (Steardo and Nathanson, 1987), we examined whether ANF treatment might also be involved in regulating protein phosphorylation in extirpated choroid plexus. ANF $(1 \mu \mathrm{M})$ increased the immunoreactivity of DARPP-32 and $I_{1}$ to $\mathrm{mAb} 23$ (Figs. 10,11), as did incubation of intact choroid plexus with the cGMP analog 8-bromo-cyclic GMP (4 mM) (Fig. 11). In whole choroid plexus, a very slight increase in cAMP level was also observed in the presence of ANF (Fig. 10). However, in experiments using isolated epithelial cells, ANF $(1 \mu \mathrm{M})$ caused no increase in cAMP content in contrast to a substantial increase in cGMP content (Fig. 12). Figure 12 also shows that dopamine $(100 \mu \mathrm{M})$ caused no increase in either cAMP or cGMP in isolated choroid epithelial cells.

\section{Discussion}

The possibility of preparing phosphorylation state-selective antibodies had been demonstrated in the case of phospho-G-sub- 


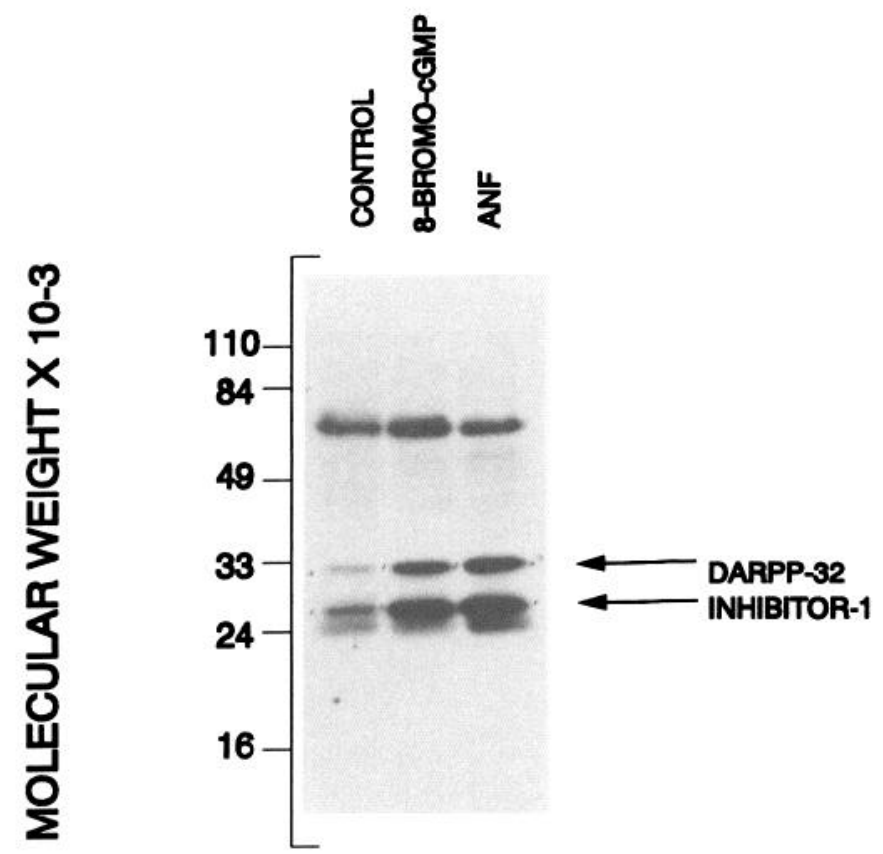

Figure 11. Effect of 8-bromo-cGMP (4 mM) and ANF (1 $\mu \mathrm{M})$ on the phosphorylation of DARPP-32 and $I_{1}$. Results are shown for a representative experiment in which whole choroid plexus (tissue from three rats/treatment) was incubated for $5 \mathrm{~min}$ in the absence (CONTROL) or the presence of either 8-bromo-cGMP $(4 \mathrm{~mm})$ or ANF $(1 \mu \mathrm{M})$. Tissue was processed for SDS-PAGE (125 $\mu \mathrm{g}$ protein/lane) and immunoblotted as described for Figure 5. Immunoblotting with mAb 23 shows increased amounts of phospho-DARPP-32 and phospho- $\mathrm{I}_{1}$ in choroid plexus incubated either with 8-bromo-cGMP or with ANF.

strate (Nairn et al., 1982), a cGMP-regulated phosphoprotein that is enriched in cerebellar Purkinje cells (Detre et al., 1984). The present study demonstrates that this strategy is generally applicable and provides an excellent tool for studying the regulation of phosphorylation of specific proteins under physiological conditions. Phospho-specific antibodies have now been generated against the cAMP-dependent protein kinase phosphorylation site (site 1) and the $\mathrm{Ca}^{2+} /$ calmodulin-dependent protein kinase II sites (sites 2 and 3 ) in synapsin I, a nerve terminalassociated protein (Czernik et al., 1989, 1991). In the present study, the recognition of phospho-DARPP-32 and phospho- $\mathrm{I}_{1}$ by the same antibody is not surprising due to the high degree of sequence homology existing between the cAMP-dependent phosphorylation sites of the two proteins (Hemmings et al., 1984c; Williams et al., 1986). mAb 23 cross-reacted with two unidentified protein bands of higher molecular weight present in brain and in choroid plexus in a manner that was independent of cAMP stimulation. These cross-reacting species did not appear to be otherwise related to DARPP-32 and/or $I_{1}$ since they were not detected using antibodies specific for these proteins. This cross-reactivity may preclude immunocytochemical applications of $\mathrm{mAb} 23$. However, when combined with electrophoretic protein separation techniques, this antibody proved to be a valuable tool in studying the regulation of DARPP-32 and $I_{1}$ phosphorylation in choroid plexus.

Choroid plexus contains high concentrations of DARPP-32 (Hemmings and Greengard, 1986) and of $\mathrm{I}_{1}$ (H. C. Hemmings, J. A. Girault, A. C. Nairn, G. Bertuzzi, and P. Greengard, unpublished observations). The present study demonstrates that DARPP-32 and $I_{1}$ are colocalized in epithelial cells, which also

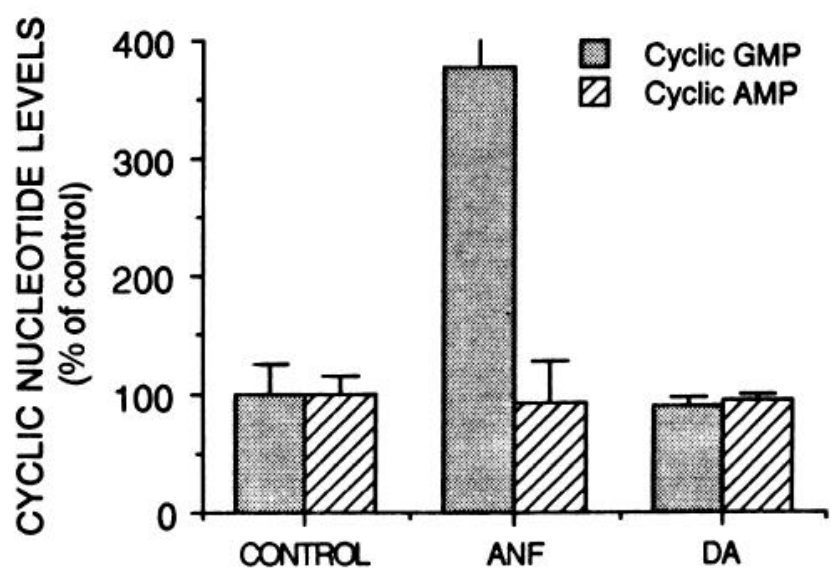

Figure 12. Effect of ANF $(1 \mu \mathrm{M})$ and dopamine $(100 \mu \mathrm{M})$ on levels of cGMP and cAMP in isolated, purified choroid plexus epithelial cells incubated in artificial CSF with drug for $3 \mathrm{~min}$. Results are expressed as a percentage of control cyclic nucleotide levels $(9.5 \pm 2.3 \mathrm{fmol} / 80,000$ cells for cGMP and $87 \pm 14 \mathrm{fmol} / 80,000$ cells for cAMP). Values shown are the mean \pm SD for duplicate tubes each assayed for cGMP and cAMP in triplicate. The results are similar to those seen in two other experiments.

contain high levels of Na,K-ATPase. Similarly, striatonigral neurons that contain high levels of DARPP-32 (Ouimet et al., 1984; Walaas et al., 1984; Hemmings and Greengard, 1986) also contain relatively high levels of $I_{1}$ (Nairn et al., 1988; Gustafson et al., 1991), while many other brain regions and tissues contain high levels of $I_{1}$ but no DARPP-32 (Gustafson et al., 1991; see also Huang and Glinsman, 1976). This suggests that, in addition to their common property of being cAMP-regulated inhibitors of phosphatase-1 (for a review, see Shenolikar and Nairn, 1991), DARPP-32 and $I_{1}$ may have distinct properties that would require their coexpression at high levels in specific cell types.

Isoproterenol and VIP increased levels of phospho-DARPP32 and phospho- $\mathrm{I}_{1}$ and also elevated cAMP levels in intact choroid plexus. Isoproterenol is known to increase cAMP formation by stimulating a $\beta_{2}$-adrenergic-sensitive adenylyl cyclase of high specific activity present in the choroid plexus (Nathanson, 1979, 1980; see also Rudman, 1977). Consistent with the observed localization of DARPP-32 and inhibitor- 1 to choroid epithelial cells (Figs. 6-8), $\beta_{2}$-adrenergic-sensitive adenylyl cyclase also is highly enriched in the secretory epithelium. VIP also is known to increase cAMP levels in choroid plexus and in choroid plexus epithelial cells (Crook et al., 1984; Lindvall et al., 1985; Crook and Prusiner, 1986) as well as in the epithelium of the related ciliary process (Mittag et al., 1985). The above data indicate an association between hormonal activation of adenylyl cyclase in choroid plexus (particularly in choroid epithelium) and hormonal stimulation of phosphorylation of DARPP-32 and $I_{1}$. This association between cAMP and phosphorylation state is further supported by the observed stimulation of phosphorylation by forskolin, a compound known to activate adenylyl cyclase directly in a variety of tissues (Seamon and Daly, 1986). Collectively, these observations suggest that several neurotransmitters and hormones that stimulate adenylyl cyclase can stimulate cAMP-dependent phosphorylation of DARPP-32.

Dopamine did not increase cAMP levels in choroid plexus and also failed to increase the phosphorylation of DARPP-32 and $I_{1}$ : These observations are consistent with the results of 
several studies that have failed to demonstrate a dopaminesensitive adenylate cyclase activity in choroid plexus (Rudman et al., 1977; Nathanson, 1979, 1980) and with several recent reports that failed to demonstrate specific binding to dopamine $\mathrm{D}_{1}$ receptors in rat choroid plexus (Nicklaus et al., 1986; Yamamoto and Kebabian, 1989). This finding is of particular significance since DARPP-32 is highly enriched in brain regions possessing high levels of $D_{1}$ receptors (Ouimet et al., 1984). The present study demonstrates the expression of DARPP-32 in cells lacking dopaminc-sensitive adenylyl cyclase. These results suggest that although DARPP-32 is abundant in dopaminoceptive cells, the expression of this phosphoprotein alone cannot be accepted as a reliable marker for dopamine receptors.

The present study also provides evidence that cAMP-independent effector systems may regulate DARPP-32 and $I_{1}$ phosphorylation in choroid plexus. Thus, ANF caused a pronounced stimulation of the phosphorylation of DARPP-32 and $I_{1}$. It also caused a very small elevation of cAMP content in the intact choroid, but no cAMP elevation in isolated epithelial cells, indicating that the slight increase occurred in some nonepithelial cell location. This latter observation is consistent with prior experiments with choroid plexus membrane preparations showing that ANF fails to activate adenylyl cyclase (Steardo and Nathanson, 1987). On the other hand, ANF (but not dopamine) elevated choroid epithelial cell cGMP levels, and it has previously been demonstrated that choroid plexus membranes contain an ANF-activated guanylyl cyclase of high specific activity enriched in the epithelium (Steardo and Nathanson, 1987). DARPP-32 and $I_{1}$ are phosphorylated in vitro by cAMP-dependent protein kinase and cGMP-dependent protein kinase on the same threonyl residue (Hemmings et al., 1984d). Because cGMP-dependent protein kinase is known to be enriched in choroid epithelial cells (Cumming et al., 1981), our results strongly suggest that ANF increases DARPP-32 and $I_{1}$ phosphorylation in choroid plexus through elevation of cGMP levels and consequent activation of cGMP-dependent protein kinase. Consistent with this hypothesis was the observation, in the present experiments, that 8-bromo-cGMP, an analog of cGMP able to penetrate cells, enhanced DARPP-32 and I, phosphorylation.

In the present experiments, 5-HT also induced substantial phosphorylation of DARPP-32 and $I_{1}$ in choroid plexus, but only a small increase in cAMP (as reported previously; scc Rudman et al., 1977; Crook et al., 1984). 5-HT receptors are present in the choroid plexus, and it has been shown that the $5-\mathrm{HT}_{\text {Ic }}$ receptor that is expressed in high density in epithelial cells (Pazos et al., 1985; Yagaloff and Hartig, 1985; Nicklaus et al., 1988) is linked to mechanisms stimulating phosphotidylinositol hydrolysis and not adenylyl cyclase (Conn et al., 1986; for review, see Curzon and Kennett, 1990; but see Rudman et al., 1977; Crook et al., 1984; present results). In broken cell preparations, we have observed that $5-\mathrm{HT}$ also causes a small stimulation ( $V_{\max }=29 \% ; K_{a}=0.1 \mu \mathrm{M}$ ) of choroid plexus guanylyl cyclase. Whether 5-HT affects DARPP-32 and $I_{1}$ phosphorylation as a consequence of guanylyl cyclase activation or as a result of phosphotidylinositol hydrolysis will require further study.

The rate of CSF secretion from choroid plexus is decreased by intravenous injection of timolol and by intraventricular injection of 5-HT and norepinephrine, the latter effect being blocked by intraventricular propranolol (Epstein et al., 1977; Feldman et al., 1979; Lindvall et al., 1979; Vogh and Godman, 1982, 1984). These observations suggest that cAMP-dependent mechanisms may decrease CSF secretion from the choroid plexus although intracerebroventricular injection of cholera toxin stimulated CSF production (see Epstein et al., 1977; for discussion, see Nathanson, 1982). Norepinephrine- and VIP-containing fibers terminate in proximity to the choroid secretory epithelium, and sympathetic stimulation or denervation alters the rate of CSF production (Lindvall et al., 1978; Lindvall and Owman, 1981). Likewise, in the ocular ciliary process, where DARPP32 is also found (Stone et al., 1986), VIP, forskolin, cholera toxin, and $\beta$-adrenergic agonists all regulate cAMP levels and decrease aqueous humor secretion (Gregory et al., 1981; Nathanson, 1981; Caprioli et al., 1984; Mittag et al., 1985; Nilsson et al., 1986; Stone et al., 1986; reviewed in Nathanson, 1985).

CAMP-independent mechanisms also appear to be involved in regulating CSF production in the choroid plexus. For instance, ANF decreases CSF production in the brain as well as aqueous humor secretion in the eye (Mittag et al., 1987; Steardo and Nathanson, 1987; Nathanson, 1988; Korenfeld and Becker, 1989). Conversely, focal increases in intracranial pressure cause an increase in circulating ANF (which has potential access to choroid epithelium through fenestrated choroidal capillaries) (J. A. Nathanson and T. Miller, unpublished observations). The effects of ANF on fluid secretion are associated with the ability of this peptide to increase cellular levels of cGMP (Hamet et al., 1984; Waldman et al., 1984) and, in the eye, are mimicked by local application of direct activators of guanylyl cyclase such as nitroglycerin (Nathanson, 1988).

It remains to be established what role the regulation of DARPP32 and $I_{1}$ phosphorylation plays in the function of the choroid plexus. However, it is quite interesting that DARPP- 32 has been localized to non-neural epithelial cells in other tissues that, like choroid plexus, are involved in fluid formation and transport, including those in the rabbit ciliary processes (Stone et al., 1986) and in the renal tubule cells of rat and monkey (Meister et al., 1989). It is intriguing that ANF-activated guanylyl cyclase and ANF regulation of fluid secretion also occur in all these epithelia. It is striking that several pathways that decrease CSF secretion (e.g., epinephrine, ANF, 5-HT), but use different second messenger systems, all enhance DARPP-32 and $I_{1}$ phosphorylation. Since these two proteins, when phosphorylated, are potent inhibitors of protein phosphatase-1, our observations suggest that inhibition of phosphatase- 1 may be part of a final common pathway involved in the control of fluid secretion. It is therefore of particular interest that a phosphopeptide derived from DARPP-32, which inhibits phosphatase-1, was able to mimic dopamine-induced inhibition of $\mathrm{Na}, \mathrm{K}$-ATPase in the renal tubules of the thick ascending limb of the loop of Henle (Aperia et al., 1991). It was also shown that cAMP-dependent protein kinase and protein kinase $\mathrm{C}$ each phosphorylate Na,K-ATPase, and that the phosphorylation is correlated with inhibition of enzyme activity (Bertorello et al., 1991). Since Na,K-ATPase, DARPP-32, and $I_{1}$ are all colocalized in choroid plexus epithelial cells, it is tempting to speculate that inhibition of $\mathrm{Na}, \mathrm{K}$ ATPase may be involved in the neural and hormonal inhibition of CSF production. Further studies of DARPP-32 and $I_{1}$ regulation in choroid plexus and in other secretory epithelia may provide important insights on the functions of these phosphoproteins.

\section{References}

Aitken A, Bilham T, Cohen P (1982) Complete primary structure of protein phosphatase inhibitor-1 from rabbit skeletal muscle. Eur $\mathrm{J}$ Biochem 126:235-246. 
Aperia A, Fryckstedt J, Svensson L, Hemmings HC Jr, Nairn AC, Greengard P (1991) Phosphorylated $M_{r} 32,000$ dopamine- and cAMP-regulated phosphoprotein inhibits $\mathrm{Na}^{+}, \mathrm{K}^{+}$-ATPase activity in renal tubule cells. Proc Natl Acad Sci USA 88:2798-2801.

Bertorello AM, Aperia A, Walaas SI, Nairn AC, Greengard P (1991) Phosphorylation of the catalytic subunit of $\mathrm{Na}^{+}, \mathrm{K}^{+}$-ATPase inhibits the activity of the enzyme. Proc Natl Acad Sci USA 88:11359-11362.

Brooker G, Terasake WL, Price MG (1976) Gammaflow: a completely automated radioimmunoassay system. Science 194:270-276.

Caprioli J, Sears M, Bauscher L, Gregory D, Mead A (1984) Forskolin lowers intraocular pressure by reducing aqueous inflow. Invest Ophthalmol Vis Sci 25:268-277.

Cohen P, Rylatt DB, Nimmo GA (1977) The hormonal control of glycogen metabolism: the amino acid sequence at the phosphorylation site of protein phosphatase inhibitor-1. FEBS Lett 76:182-186.

Conn PJ, Sanders-Bush E, Hoffman BJ, Hartig PR (1986) A unique serotonin receptor in choroid plexus is linked to phosphatidylinositol turnover. Proc Natl Acad Sci USA 83:4086-4088.

Crook RB, Prusiner SB (1986) Vasoactive intestinal peptide stimulates cyclic AMP metabolism in choroid plexus epithelial cells. Brain Res 384:138-144.

Crook RB, Farber MB, Prusiner SB (1984) Hormones and neurotransmitters control cyclic AMP metabolism in choroid plexus epithelial cells. J Neurochem 42:340-350.

Cserr H (1971) Physiology of the choroid plexus. Physiol Rev 51:273311.

Cumming R, Cheung W-Y, Wallace R, Steiner A (1981) Immunofluorescent localization of cyclic GMP, calmodulin and cyclic GMPdependent protein kinase in the choroid plexus. Neurosci Lett 22: 119-124.

Curzon G, Kennett G (1990) m-CPP: a tool for studying behavioural responses associated with $5-\mathrm{HT} 1_{c}$ receptors. Trends Pharmacol Sci 11:181-182.

Czernik AJ, Girault J-A, Greengard P (1989) Phospho- and dephospho-specific antibodies for phosphorylation site 1 of synapsin I. J Cell Biol 109:215a.

Czernik AJ, Girault J-A, Nairn AC, Chen JC, Snyder GL, Kebabian JW, Greengard P (1991) Production of phosphorylation-state specific antibodies. Methods Enzymol 201:264-283.

Detre JA, Nairn AC, Aswad DW, Greengard P (1984) Localization in mammalian brain of G-substrate, a specific substrate for guanosine 3,5'-cyclic-monophosphate-dependent protein kinase. J Neurosci 4: 2843-2849.

Ehrlich ME, Kurihara T, Greengard P (1990) Rat DARPP-32: cloning, sequencing, and characterization of the cDNA. J Mol Neurosci 2:110.

Elbrecht A, Direnzo A, Smith RG, Shenolikar S (1990) Molecular cloning of protein phosphatase inhibitor- 1 and its expression in rat and rabbit tissue. J Biol Chem 265:13415-13418.

Epstein M, Feldman A, Brusilow S (1977) Cerebrospinal fluid production: stimulation by cholera toxin. Science 196:1012-1013.

Feldman A, Epstein M, Brusilow S (1979) Effect of cholera toxin and prostaglandins on the rat choroid plexus in vitro. Brain Res 167:119128.

Girault J-A, Shalaby IA, Rosen NL, Greengard P (1988) Regulation by cAMP and vasoactive intestinal peptide of phosphorylation of specific proteins in striatal cells in culture. Proc Natl Acad Sci USA 85:7790-7794

Girault J-A, Raisman-Vozari R, Agid Y, Greengard P (1989) Striatal phosphoproteins in Parkinson's disease and progressive supranuclear palsy. Proc Natl Acad Sci USA 86:2493-2497.

Gregory D, Sears M, Bauscher L, Mishima H, Mead A (1981) Intraocular pressure and aqueous flow are decreased by cholera toxin. Invest Ophthalmol Vis Sci 20:371-381.

Gustafson EL, Girault J-A, Hemmings HC Jr, Nairn AC, Greengard, $P$ (1991) Immunocytochemical localization of phosphatase inhibitor-1 in rat brain. J Comp Neurol 310:170-188.

Hamet P, Tremblay J, Pang SC, Garcia R, Thibault G, Gutkowska J, Cantin M, Genest J (1984) Effect of native and synthetic atrial natriuretic factor on cyclic GMP. Biochem Biophys Res Commun 123:515-527.

Hemmendinger LM, Garber BB, Hoffmann PC, Heller A (1981) Target neuron-specific process formation by embryonic mesencephalic dopamine neurons in vitro. Proc Natl Acad Sci USA 78:1264-1268.

Hemmings HC Jr, Greengard P (1986) DARPP-32, a dopamine- and adenosine $3^{\prime}: 5^{\prime}$-monophosphate-regulated phosphoprotein: regional tissue, and phylogenetic distribution. J Neurosci 6:1469-1481.

Hemmings HC Jr, Greengard P, Tung HYL, Cohen P (1984a) DARPP32, a dopamine-regulated neuronal phosphoprotein, is a potent inhibitor of protein phosphatase-1. Nature 310:503-505.

Hemmings HC Jr, Nairn AC, Aswad DW, Greengard P (1984b) DARPP-32, a dopamine- and adenosine $3^{\prime}: 5^{\prime}$-monophosphate-regulated phosphoprotein enriched in dopamine-innervated brain regions. II. Purification and charactcrization of the phosphoprotein from bovine caudate nucleus. J Neurosci 4:99-110.

Hemmings HC Jr, Williams KR, Konigsberg WH, Greengard P (1984c) DARPP-32, a dopamine- and adenosine $3^{\prime}: 5^{\prime}$-monophosphate-regulated neuronal phosphoprotein. I. Amino acid sequence around the phosphorylated threonine. J Biol Chem 259:14486-14490.

Hemmings HC Jr, Nairn AC, Greengard P (1984d) DARPP-32, a dopamine- and adenosine $3^{\prime}: 5^{\prime}$-monophosphate-regulated phosphoprotein enriched in dopamine-innervated brain regions. II. Comparison of the kinetics of phosphorylation of DARPP-32 and phosphatase inhibitor 1. J Biol Chem 259:14491-14497.

Hodges RS, Merrifield RB (1975) Solid phase synthesis. Anal Biochem 65:241-272.

Huang FL, Glinsmann WH (1976) Preparation and characterization of two phosphorylase phosphatase inhibitors from rabbit skeletal muscle. Eur J Biochem 70:419-426.

Ingebritsen T, Cohen P (1983) The protein phosphatases involved in cellular regulation. 1. Classification and substrate specificities. Eur J Biochem 132:255-261.

Ingebritsen T, Stewart AA, Cohen P (1983) The protein phosphatases involved in cellular regulation. 6 . Measurement of type- 1 and type- 2 protein phosphatases in extracts of mammalian tissues; an assessment of their physiological roles. Eur J Biochem 132:297-307.

Johanson CE (1989) Potential for pharmacological manipulation of the blood-cerebrospinal fluid barrier. In: Implications of the bloodbrain barrier and its manipulation, Vol 1 (Neuwelt E, ed), pp 223260. New York: Plenum.

Kaczmarek LK, Jennings KR, Strumwasser R, Nairn AC, Walter U, Wilson FD, Greengard P (1980) Microinjection of catalytic subunit of cyclic AMP-dependent protein kinase enhances calcium action potentials of bag cell neurons in cell culture. Proc Natl Acad Sci USA 77:7487-7491.

Kohler G, Milstein C (1975) Continuous cultures of fused cells secreting antibody of predefined specificity. Nature 256:495-497.

Korenfeld MS, Becker B (1989) Atrial natriuretic peptides: effects on intraocular-pressure, cGMP, and aqueous flow. Invest Ophthalmol Vis Sci 30:2385-2392.

Laemmli UK (1970) Cleavage of structural proteins during the assembly of the head of bacteriophage T4. Nature 227:680-685.

Lindvall M, Owman C (1981) Autonomic nerves in the mammalian choroid plexus and their influence on the formation of cerebrospinal fluid. J Cereb Blood Flow Metab 1:245-266.

Lindvall M, Edvinsson L, Owman C (1978) Sympathetic nervous control of cerebrospinal fluid production from the choroid plexus. Science 201:176-178.

Lindvall M, Edvinsson L, Owman C (1979) Effect of sympathomimetic drugs and corresponding receptor antagonists on the rate of cerebrospinal fluid production. Exp Neurol 64:132-145.

Lindvall M, Gustafson A, Hedner P, Owman C (1985) Stimulation of cyclic AMP formation in rabbit choroid plexus by beta-adrenergic agonists and VIP. Neurosci Lett 54:153-157.

Lowry OH, Rosebrough NJ, Farr AL, Randall RJ (1951) Protein measurement with the Folin phenol reagent. J Biol Chem 193:265275.

Meister B, Fryckstedt J, Schalling M, Cortes R, Hokfelt T, Aperia A, Hemmings HC Jr, Nairn AC, Ehrlich ME, Greengard P (1989) Dopamine- and cAMP-regulated phosphoprotein (DARPP-32) and dopamine $D_{1}$ agonist-sensitive $\mathrm{Na}^{+}, \mathrm{K}^{+}$-ATPase in renal tubule cells. Proc Natl Acad Sci USA 86:8068-8072.

Milhorat TH (1976) Structure and function of choroid plexus and other sites of cerebrospinal fluid formation. Int Rev Cytol 47:225287.

Mittag T, Tormay A, Podos SM (1985) The VIP-adenylate cyclase system in rabbit ciliary processes. Invest Ophthalmol Vis Sci 26:5.

Mittag T, Tormay A, Ortega N, Severin C (1987) Atrial natriuretic peptide, guanylate cyclase, and intraocular pressure. Curr Eye Res 6: 1189-1196. 
Nairn AC, Detre JA, Casnellie JE, Greengard P (1982) Serum antibodies that distinguish between the phospho- and dephospho-forms of a phosphoprotein. Nature 299:734-736.

Nairn AC, Hemmings HC Jr, Walaas SI, Greengard P (1988) DARPP32 and phosphatase inhibitor-1, two structurally related inhibitors of protein phosphatase-1, are both present in striatonigral neurons. J Neurochem 50:257-262.

Nathanson JA (1979) Beta-adrenergic-sensitive adenylate cyclase activity in sccrctory cells of choroid plexus. Science 204:843-844.

Nathanson JA (1980) Beta-adrenergic-sensitive adenylate cyclase in choroid plexus: properties and cellular localization. Mol Pharmacol 18:199-209.

Nathanson JA (1981) Effects of a potent and specific beta adreno- $^{2}$ ceptor antagonist on intraocular pressure. $\mathrm{Br} \mathrm{J}$ Pharmacol 73:97-100.

Nathanson JA (1982) Hormone regulation of cerebrospinal fluid and aqueous humor. Trends Pharmacol Sci 3:452-454.

Nathanson JA (1985) Beta-adrenergic regulation of intraocular pressure: ambiguities and insights. Trends Auton Pharmacol 3:173-186.

Nathanson JA (1988) Direct application of a guanylate cyclase activator lowers intraocular pressure. Eur J Pharmacol 147:155-156.

Nathanson JA, Chun LLY (1989) Immunological function of the bloodCSF-barrier. Proc Natl Acad Sci USA 86:1684-1688.

Nestler EJ, Greengard P (1984) Protein phosphorylation in the nervous system. New York: Wiley.

Nicklaus KL, McGonigle P, Molinoff PB (1988) [ $\left.{ }^{3} \mathrm{H}\right] \mathrm{SCH} 23390$ labels both dopamine- 1 and 5 -hydroxytryptamine- $1_{\mathrm{c}}$ receptors in the choroid plexus. J Pharmacol Exp Ther 247:343-348.

Nilsson S, Sperber G, Bill A (1986) Effects of VIP on intraocular pressure, facility of outflow and formation of aqueous humor in the monkey. Exp Eye Res 43:849-857.

Nimmo GA, Cohen P (1978) The regulation of glycogen metabolism. Purification and characterization of protein phosphatase inhibitor-1 from rabbit skeletal muscle. Eur J Biochem 87:341-351.

Ouimet CC, Miller PE, Hemmings HC Jr, Walaas SI, Greengard P (1984) DARPP-32, a dopamine- and adenosine $3^{\prime}: 5^{\prime}$-monophosphate-regulated phosphoprotein enriched in dopamine-innervated brain regions. III. Immunocytochemical localization. J Neurosci 4: 114-124.

Pazos A, Hoyer D, Palacios JM (1985) The binding of serotonergic ligands to the porcine choroid plexus: characterization of a new type of serotonin recognition site. Eur J Pharmacol 106:539-546.

Rudman D, Hollins BM, Lewis NC, Scott JW (1977) Effects of hormones on $3^{\prime}, 5^{\prime}$-cyclic adenosine monophosphate in choroid plexus. Am J Physiol 232:E353-E357.

Seamon KB, Daly JW (1986) Forskolin-its biological and chemical properties. Adv Cyclic Nucleotide Protein Phosphorylation Res 20: $1-149$.
Shenolikar S, Nairn AC (1991) Protein phosphatases: recent progress. Adv Second Messenger Phosphoprotein Res 23:1-121.

Smith PK, Krohn RI, Hermanson GT, Mallia AK, Gartner FH, Provenzano MD, Fujimoto EK, Goeke NM, Olson BJ, Klenk DC (1985) Measurement of protein using bicinchoninic acid. Anal Biochem 150: $76-85$.

Steardo L, Nathanson JA (1987) Brain barrier tissue: end organs for atriopeptins. Science 235:470-473.

Stone RA, Laties AM, Hemmings HC Jr, Ouimet CC, Greengard P (1986) DARPP-32 in the ciliary epithelium of the eye: a neurotransmitter-regulated phosphoprotein of brain localizes to secretory cells. J Histochem Cytochem 34:1465-1468.

Sweadner K, Gilkeson R (1985) Two isozymes of the Na,K-ATPase have distinct antigenic determinants. J Biol Chem 260:9016-9022.

Towbin H, Staehlin I, Gordon J (1979) Electrophoretic transfer of proteins from polyacrylamide gels to nitrocellulose sheets: procedure and some applications. Proc Natl Acad Sci USA 76:4350-4354.

Vogh B, Godman D (1982) Cerebrospinal fluid formation in rats and cats during treatment with timolol. Can J Physiol Pharmacol 60: $1138-1143$

Vogh B, Godman D (1984) Addition of the effects of norepinephrine and acetazolamide to decrease formation of cerebrospinal fluid. $J$ Pharmacol Exp Ther 229:207-209.

Walaas SI, Greengard P (1984) DARPP-32, a dopamine- and adenosine $3^{\prime}: 5^{\prime}$-monophosphate-regulated phosphoprotein enriched in dopamine-innervated brain regions. I. Regional and cellular distribution in rat brain. J Neurosci 4:84-98.

Walaas SI, Aswad DW, Greengard P (1983a) A dopamine- and cyclic AMP-regulated phosphoprotein enriched in dopamine-innervated brain regions. Nature 301:69-71.

Walaas SI, Nairn AC, Greengard P (1983b) Regional distribution of calcium-and cyclic adenosine $3^{\prime}: 5^{\prime}$-monophosphate-regulated protein phosphorylation systems in mammalian brain. II. Soluble systems. J Neurosci 3:302-311.

Waldman SA, Rapoport RM, Murad F (1984) Atrial natriuretic factor selectively activates particulate guanylate cyclase and elevates cyclic GMP in rat tissues. J Biol Chem 259:14332-14334.

Williams KR, Hemmings HC Jr, LoPresti MB, Konigsberg WH, Greengard P (1986) DARPP-32, a dopamine- and cyclic AMP-regulated neuronal phosphoprotein. Primary structure and homology with protein phosphatase inhibitor-1. J Biol Chem 261:1890-1903.

Yagaloff KA, Hartig PR (1985) ${ }^{125}$ I-lysergic acid diethylamide binds to a novel serotonergic site on rat choroid plexus epithelial cells. J Neurosci 5:3178-3183.

Yamamoto T, Kebabian JW (1989) $\left[\mathbf{I}^{125}\right] \mathrm{SCH} 23982$ binds to a serotonin receptor (and not to a $D_{1}$ dopamine receptor) in rat choroid plexus. Biog Amines 6:241-246. 